\title{
Plasticity in the Link between Pain-Transmitting and Pain-Modulating Systems in Acute and Persistent Inflammation
}

\author{
QiLiang Chen ${ }^{1}$ and Mary M. Heinricher ${ }^{1,2}$ \\ Departments of ${ }^{1}$ Neurological Surgery and ${ }^{2}$ Behavioral Neuroscience, Oregon Health \& Science University, Portland, Oregon 97239
}

There is strong evidence that spinoparabrachial neurons in the superficial dorsal horn contribute to persistent pain states, and that the lateral parabrachial complex $(\mathrm{PB})$ conveys relevant nociceptive information to higher structures. The role of $\mathrm{PB}$ itself in hyperalgesia and how it recruits descending facilitation has nevertheless received significantly less attention. The current study is a first step toward delineating the functional dynamics of $\mathrm{PB}$ and its link to descending control in acute and persistent inflammatory pain. In lightly anesthetized rats, we recorded behavioral withdrawal evoked by mechanical stimulation of the hindpaw and, simultaneously, the activity of identified pain-modulating neurons, "ON-cells" and "OFF-cells," in the rostral ventromedial medulla (RVM). This was done before and after the inactivation of $\mathrm{PB}$, contralateral or ipsilateral to an inflamed paw [1 h, $1 \mathrm{~d}$, or 5- $6 \mathrm{~d}$ after intraplantar injection of Complete Freund's Adjuvant (CFA)]. The inactivation of contralateral, but not ipsilateral, PB interfered with nociceptive input to RVM under basal conditions, as well as in acute inflammation. By contrast, blocking ipsilateral, but not contralateral, PB in established inflammation interfered with behavioral hyperalgesia and ON-cell and OFF-cell responses. The lesioning of contralateral PB before CFA injection prevented this recruitment of ipsilateral $\mathrm{PB}$ in persistent inflammation. These experiments show that contralateral $\mathrm{PB}$ is required to initiate hyperalgesia, which is then maintained by ipsilateral PB, most likely in both cases via the engagement of pain-modulating neurons of the RVM.

Key words: brainstem; inflammation; pain-modulation; raphe; rat; RVM

Significance Statement

The lateral parabrachial complex (PB) relays nociceptive information to brain circuits that are important for the transmission and modulation of pain, but its specific role in persistent pain and engagement of descending control mechanisms has received relatively little attention. We show here that PB contralateral and ipsilateral to an inflammatory insult demonstrate different functions as inflammation persists, likely by engaging pain-facilitating neurons of the rostral ventromedial medulla. While the contralateral $\mathrm{PB}$, the target of the major spinoparabrachial pathway, relays acute nociceptive information, the ipsilateral PB is recruited or unmasked in persistent inflammation to maintain hyperalgesia. These data point to plasticity in the PB itself or its direct and indirect connections with pain-modulating systems as central to the development and maintenance of persistent pain.

\section{Introduction}

Plasticity in pain-processing circuitry is recognized to play a major role in persistent pain. Plasticity in the ascending pain transmission system is well characterized, particularly at the level of the primary afferent and dorsal horn. Plasticity in painmodulating circuits mediating descending control has been less studied, although increasingly recognized as important (Porreca

\footnotetext{
Received Oct. 3, 2018; revised Dec. 26, 2018; accepted Jan. 4, 2019.

Author contributions: Q.C. and M.M.H. designed research; Q.C. performed research; Q.C. and M.M.H. analyzed data; Q.C. wrote the paper.

This research was supported by National Institutes of Health Grants NS-093894, DA-042565, and F31-NS087634.

The authors declare no competing financial interests.

Correspondence should be addressed to Mary M. Heinricher at heinricm@ohsu.edu.

Q. Chen's present address: Department of Surgery, Stanford University, Stanford, CA 94305.

https://doi.org/10.1523/JNEUROSCI.2552-18.2019

Copyright $\odot 2019$ the authors $\quad 0270-6474 / 19 / 392065-15 \$ 15.00 / 0$
}

et al., 2002; Ren and Dubner, 2002; Heinricher and Fields, 2013; Heinricher, 2016). The output node of the principal descending control system, the rostral ventromedial medulla (RVM), undergoes structural, molecular, and pharmacological plasticity in persistent pain models, and the responsiveness of identified RVM pain-modulating neurons is enhanced (Heinricher and Fields, 2013; Heinricher, 2016). The major relay through which acute noxious stimuli gain access to the RVM was recently shown to be the lateral parabrachial complex (PB; Roeder et al., 2016; Chen et al., 2017).

$\mathrm{PB}$ receives a substantial projection from nociceptive neurons in the contralateral superficial dorsal horn, with a less dense input from the ipsilateral superficial dorsal horn and from deeper laminae (Bernard et al., 1995; Feil and Herbert, 1995; Bester et al., 2000b; Polgár et al., 2010). Many lateral PB neurons respond to acute noxious stimuli (Bester et al., 1995, 2000a; Hermanson and 
Blomqvist, 1996; Uddin et al., 2018). Selective activation of a subset of $\mathrm{PB}$ neurons or inputs elicits aversive behaviors (Han et al., 2015) and supports conditioned aversion (Rodriguez et al., 2017). Although the inactivation of lateral PB produces only modest hypoalgesia in acute pain tests (Roeder et al., 2016), indirect evidence suggests a role for this structure in potentiated or persistent pain states. Thus, a large proportion of superficial dorsal horn neurons projecting to $\mathrm{PB}$ express the neurokinin 1 (NK1) receptor, and the elimination of NK1-expressing neurons interferes with persistent hyperalgesia in animal models of inflammatory and neuropathic pain (Nichols et al., 1999; Todd et al., 2000; Suzuki et al., 2002; Khasabov et al., 2005; Rivat et al., 2009). Hyperalgesia mediated by spinal NK1-positive neurons is thought to require a supraspinal loop that engages descending facilitation (Suzuki et al., 2002). However, there is also evidence that ascending projections from $\mathrm{PB}$ to the amygdala contribute to persistent pain, and specifically to the affective dimension of pain (Han et al., 2015; Thompson and Neugebauer, 2017), although these projections are distinct from those to the RVM (Roeder et al., 2016).

The goal of the current study was to determine whether PB contributes to inflammation-induced behavioral hypersensitivity and regulates the activity of identified pain-modulating neurons in the RVM. We tested the effect of blocking PB either contralateral or ipsilateral to an inflammatory stimulus [intraplantar injection of Complete Freund's Adjuvant (CFA)] acutely, and at 1 or 5-6 d postinjection. Our previous studies on the role of $\mathrm{PB}$ in responses evoked by acute noxious stimuli pointed to contralateral $\mathrm{PB}$ as the critical relay of nociceptive information to the RVM, with no contribution from PB ipsilateral to the stimulus site (Roeder et al., 2016). This observation was consistent with the dense projection from the superficial dorsal horn to the contralateral $\mathrm{PB}$. However, PB receives input from the ipsilateral superficial dorsal horn, although it is much less dense (Bernard et al., 1995; Feil and Herbert, 1995; Bester et al., 2000b; Todd et al., 2000; Polgár et al., 2010). Moreover, lateral PB neurons typically have large bilateral, even whole-body, receptive fields (Bester et al., 1995; Uddin et al., 2018). In addition, c-fos studies document the bilateral activation of $\mathrm{PB}$ in response to noxious stimuli, albeit with a contralateral predominance. Interestingly, this contralateral predominance diminishes with persistent inflammation (Bellavance and Beitz, 1996), raising the possibility that $\mathrm{PB}$ ipsilateral to an inflammatory insult contributes to behavioral hypersensitivity.

In the present experiments, we found that the contralateral and ipsilateral PB demonstrate distinct functions as inflammation persists over a period of days. Contralateral $\mathrm{PB}$ relays nociceptive information to RVM in acute inflammation and contributes to behavioral hyperalgesia, whereas ipsilateral PB maintains both hyperalgesia and responsiveness of RVM neurons in persistent inflammation.

\section{Materials and Methods}

All experimental procedures were approved by the Institutional Animal Care and Use Committee at Oregon Health \& Science University and followed the guidelines of the Committee for Research and Ethical Issues of the International Association for the Study of Pain.

\section{Subjects}

Male Sprague Dawley rats were purchased from Charles River and acclimated for at least $3 \mathrm{~d}$ in the vivarium with a $12 \mathrm{~h}$ light/dark cycle and food and water available ad libitum. Males were used to allow comparison with previous experiments in animals not subjected to inflammation (Roeder et al., 2016; Chen et al., 2017) and because of the lack of an established protocol in females for maintaining the necessary stable experimental plane. All preparations and experiments were performed during the light phase.

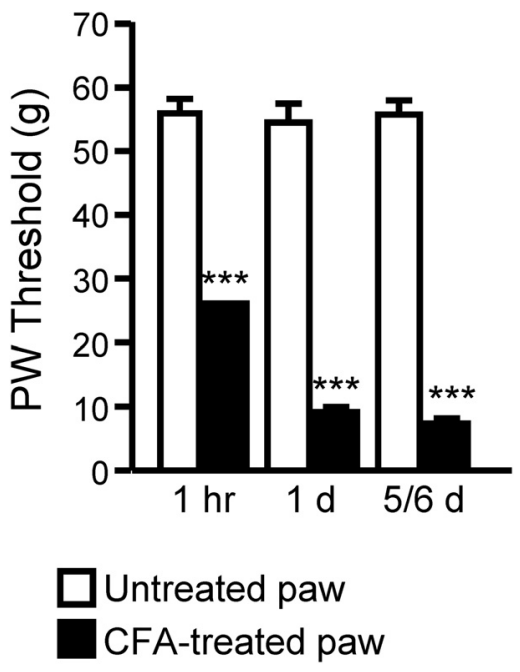

Figure 1. CFA produces acute and persistent mechanical hyperalgesia. The effect of intraplantar CFA injection on the withdrawal threshold measured either acutely (within the first hour following injection, $n=24)$, $1 \mathrm{~d}$ postinjection $(n=18)$, and 5 or $6 \mathrm{~d}$ postinjection $(n=23)$. The untreated paw is shown for comparison. Two-way repeated-measures ANOVA was followed by Sidak's multiple-comparisons test to compare (FA-treated and untreated paws. There was a significant effect of paw $\left(F_{(1,62)}=713.7, p<0.0001\right)$, time $\left(F_{(2,62)}=17.6, p<0.0001\right)$, and paw $\times$ time interaction $\left(F_{(2,62)}=15.0, p<0.0001\right)$. Values are the mean + SEM. ${ }^{* *} p<$ 0.0001 compared with untreated paw. PW, Paw withdrawal.

\section{Persistent inflammation}

For experiments involving persistent inflammation, naive or PBlesioned male Sprague Dawley rats weighing between 250 and 350 g were briefly anesthetized with isoflurane (4\%, 4-5 min). CFA (0.1 ml; SigmaAldrich) was injected subcutaneously into the plantar surface of the hindpaw, after which the rat was returned to its home cage for either $1 \mathrm{~d}$ or 5-6 d until the electrophysiological experiment. Injections were typically made in the left hindpaw. Although there is evidence for the lateralization of persistent pain processing at the level of the amygdala (Carrasquillo and Gereau, 2008), we saw no indication of lateralization at the level of PB in a previous study (Roeder et al., 2016). Laterality was therefore not added as an additional variable in the present design. Inflammation induced by CFA typically peaks at $1 \mathrm{~d}(24 \mathrm{~h})$, but is maintained for $\geq 2$ weeks. These time points were therefore chosen as consistent with the known duration of behavioral hypersensitivity following plantar CFA administration and with the known time course of changes in RVM activity after CFA injection (Ren and Dubner, 1996; Guan et al., 2002, 2003; Cleary and Heinricher, 2013; Maduka et al., 2016).

\section{Electrophysiological experiments}

Animal preparation. On the day of the experiment, animals were deeply anesthetized (5\% isoflurane in oxygen) and a catheter inserted in the external jugular vein for subsequent infusion of methohexital, a shortacting barbiturate. They were then transferred to a stereotactic frame. While animals were still deeply anesthetized, two small craniotomies were drilled for access to the RVM and the PB. Heart rate was monitored using EKG. Body temperature was monitored and maintained at 36$37^{\circ} \mathrm{C}$ with a heating pad and a room space heater.

After the surgical preparation, the rate of methohexital infusion was adjusted so that animals displayed no spontaneous movement or apparent distress, while allowing a stable heat-evoked hindpaw withdrawal reflex. Animals were stabilized for at least $45 \mathrm{~min}$ at a constant anesthetic flow rate before beginning data collection.

Electrophysiological recording. Extracellular single-unit recordings were made with stainless steel microelectrodes (MicroProbes for Life Sciences) with gold- and platinum-plated tips. Signals were amplified (10,000×), sampled at $32,000 \mathrm{~Hz}$, and bandpass filtered $(400 \mathrm{~Hz}$ to $15 \mathrm{kHz})$.

Two classes of functionally distinct neurons, the pain-facilitating "ON-cells" and the pain-inhibiting "OFF-cells" are found in the RVM 


\section{Naive}

a

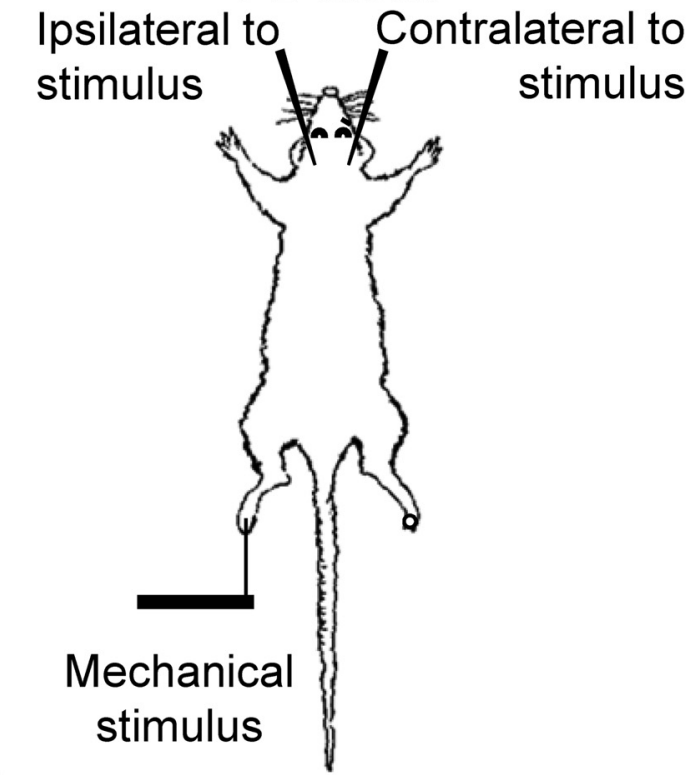

b
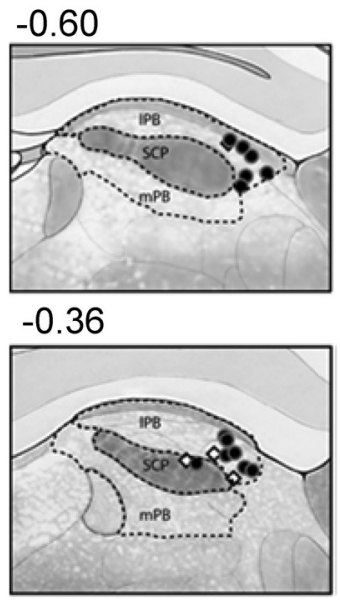

$-0.24$

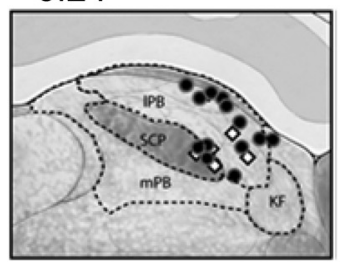

c Contralateral to stimulus
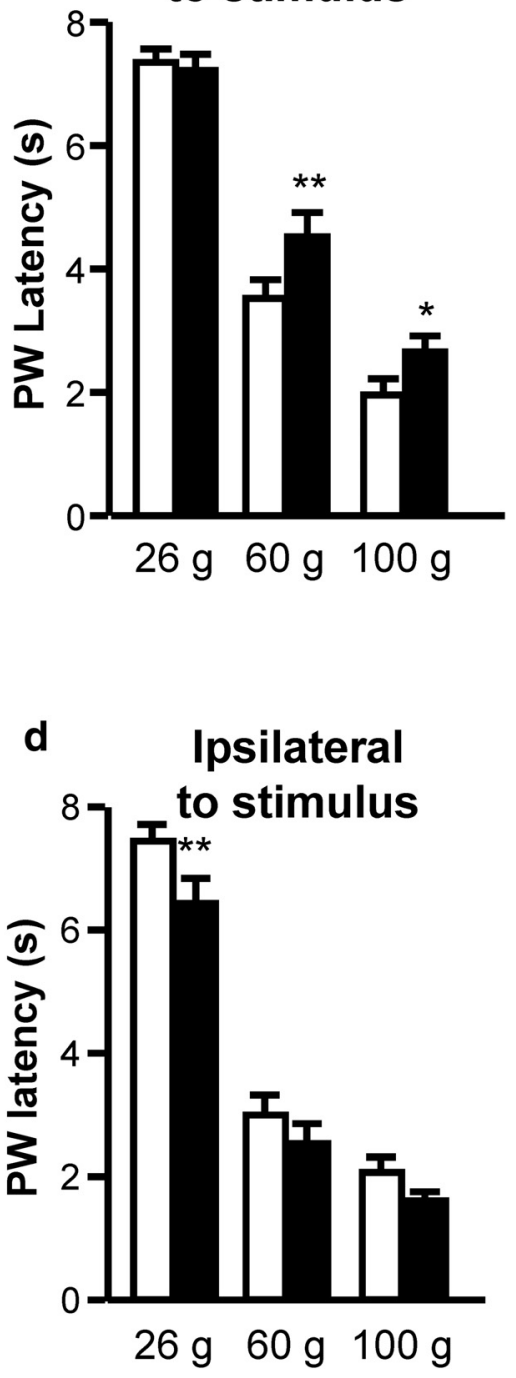

$\square$ Pre-block PB block

Figure 2. Inactivation of lateral PB contralateral to the stimulation site produced significant hypoalgesia in naive animals. $\boldsymbol{a}$, Schematic of experimental setup with PB block contralateral or ipsilateral to paw stimulation in naive animals. $\boldsymbol{b}$, Locations of microinjection sites in the lateral PB complex for experiments in naive animals (this figure, Fig. 3) and animals with a (FA-treated paw contralateral to the PB target (Figs. 4, 5, 6, 7, 8). Parabrachial injections were distributed among sections at +0.24 to $-0.60 \mathrm{~mm}$ relative to the interaural line. Injections inside the lateral PB (IPB) region were considered to be on-target. White diamonds represent naive animals. Black circles represent animals with CFA-induced inflammation. KF, Kölliker-Fuse; mPB, medial parabrachial area; scp, superior cerebellar peduncle. c, PW (paw withdrawal) latencies in preblock baseline and during the block of contralateral PB. Contralateral PB block led to modest hypoalgesia $(n=27)$. There was a significant effect of block $\left(F_{(1,26)}=8.16, p=0.0083\right)$, force $\left(F_{(2,52)}=177.8, p<0.0001\right)$, and block $\times$ force interaction $\left(F_{(2,52)}=4.84, p=0.012\right)$. $\boldsymbol{d}$, PW latencies in preblock baseline and during block of ipsilateral PB. Ipsilateral PB block produced modest hyperalgesia, with a significant decrease in latency to withdrawal to the $26 \mathrm{~g}$ fiber $(n=21)$. There was a significant effect of block $\left(F_{(1,20)}=18.7, p=0.0003\right)$ and force $\left(F_{(2,40)}=182.0, p<0.0001\right)$, with no block $\times$ force interaction $\left(F_{(2,40)}=0.95, p=0.40\right)$. Two-way ANOVA with repeated measures on both force and block, followed by Sidak's test for multiple comparisons when effect of block was significant. Mean $+\mathrm{SEM},{ }^{*} p<0.05,{ }^{* *} p<0.01$ compared with preblock baseline at that force.

(Heinricher et al., 2009; Heinricher and Fields, 2013; Heinricher, 2016). RVM neurons were isolated and classified as ON- or OFF-cells, as described previously (Cleary and Heinricher, 2013; Roeder et al., 2016), using a Peltier device applied to the plantar surface of the hindpaw (Yale
Instruments; $35^{\circ} \mathrm{C}$ holding temperature, increased at a rate of $1.2^{\circ} \mathrm{C} / \mathrm{s}$ from $35^{\circ} \mathrm{C}$ to a maximum of $53^{\circ} \mathrm{C}$ ). Both $\mathrm{ON}$ - and OFF-cells have wholebody receptive fields, but inverse responses during nocifensive behaviors. ON-cells exhibit a "burst" of activity (if not already active), while OFF- 

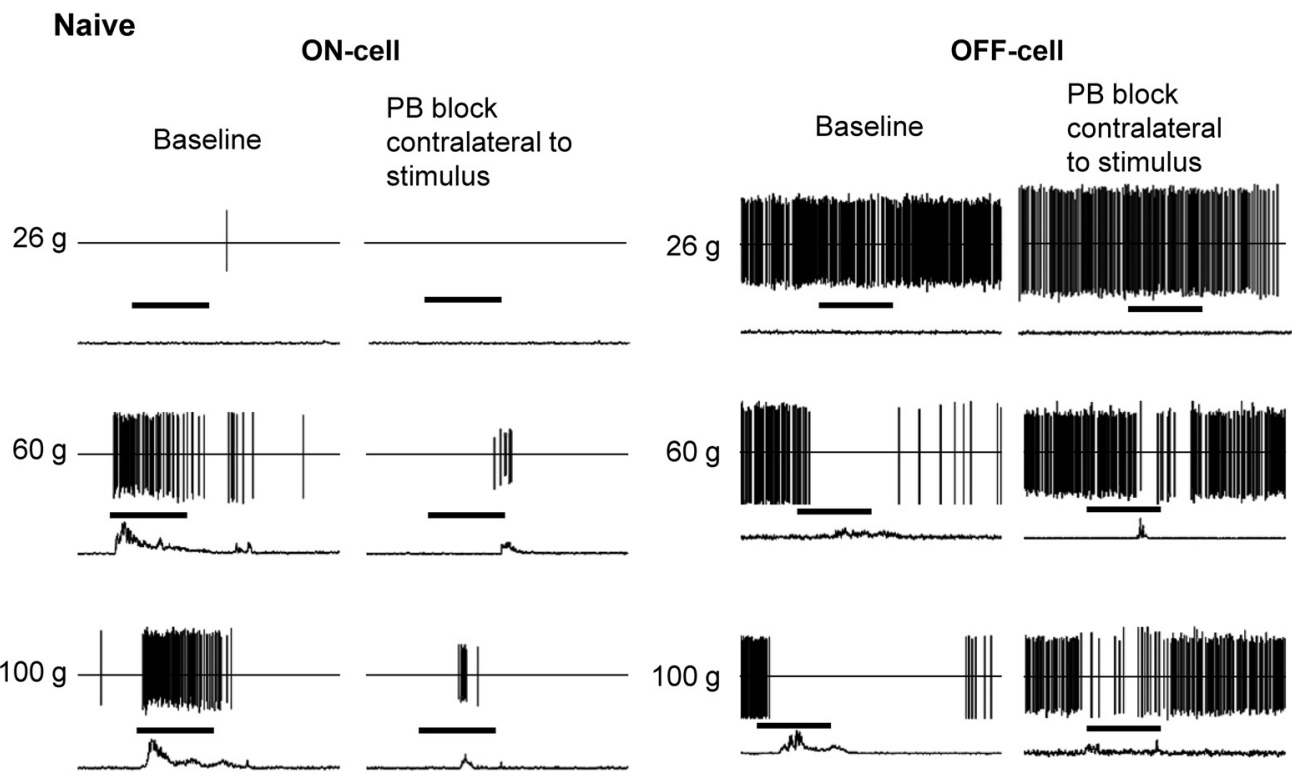

$100 \mathrm{~g}$
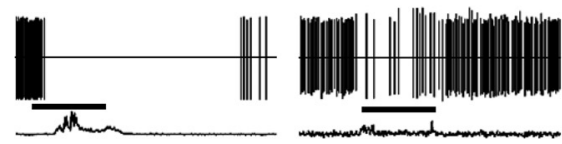

von Frey stimulation (8s)

Figure 3. Inactivation of PB interfered with the $\mathrm{ON}$-cell burst and OFF-cell pause evoked by mechanical stimulation of the paw contralateral to the block in naive animals. Representative examples show $0 \mathrm{~N}$ - and $0 \mathrm{FF}$-cell activity associated with withdrawal from the Von Frey probe $(26,60$, and $100 \mathrm{~g})$ during preblock baseline contrasted with that during PB block contralateral to the stimulus. In both cell classes, reflex-related changes in firing were substantially reduced.

cells exhibit a "pause" of any ongoing activity (if active), or remain silent (if inactive). To further confirm cell classification, a 10 s noxious pinch was delivered to the hindpaw using a toothed forceps: ON-cells burst and OFF-cells pause throughout such a maintained stimulus. Anesthetic depth and cell identification were assessed regularly throughout the experiment using heat stimulations. One neuron was studied in a typical experiment, although two or more neurons were simultaneously recorded in the same animal on 18 occasions.

$P B$ block. During electrophysiological recording, the $\mathrm{GABA}_{\mathrm{A}}$ receptor agonist muscimol [1 ng/200 $\mathrm{nl}$ in artificial CSF (aCSF); Tocris Bioscience] was delivered to the lateral PB using a glass microinjector $(70 \mu \mathrm{m}$ outer diameter, attached to a $1 \mu \mathrm{l}$ Hamilton syringe via PE-50 tubing) to provide a long-lasting, stable inhibition of local neuronal activity. Vehicle controls were not used for two reasons. First, the goal of these studies was not to examine GABAergic mechanisms in $\mathrm{PB}$, but to compare the effects of block at different time points with each other (see Experimental design, below). Second, previous reports have shown that infusions of aCSF in PB have no effect on the activity of RVM neurons or nocifensive behaviors and demonstrated that infusions of a short-acting local anesthetic (lidocaine) have effects comparable to those of muscimol, as does optogenetic inactivation of PB projections to RVM (Roeder et al., 2016; Chen et al., 2017). Lateral PB was chosen because this region is functionally most relevant to nociceptive processing, and has a denser concentration of RVM-projecting neurons than other components of PB (Bernard et al., 1989; Hermanson and Blomqvist, 1996; Bourgeais et al., 2001; Roeder et al., 2016). Moreover, anatomical controls, in which block of medial PB or surrounding areas were shown to have no effect, pointed to lateral PB specifically as having a functional influence on RVM activity (Roeder et al., 2016). Green fluorescent beads (FluoSpheres, Invitrogen) were included in the drug solutions in a 1:100 concentration for post hoc verification of the injection site. Injectors were rinsed and lowered into the brain using stereotactic coordinates for the lateral PB [anteroposterior $(\mathrm{AP}),-1.2 \mathrm{~mm}$ with the injector directed caudally at $14^{\circ}$; mediolateral (ML), $+2.3 \mathrm{~mm}$; dorsoventral (DV) +3 , relative to interaural zero; level head]. Injections were made over a period of $4 \mathrm{~min}$.

\section{Excitotoxic lesion of lateral $P B$}

In a subset of experiments, an excitotoxic lesion was made in the left lateral $\mathrm{PB}$, which was contralateral to the hindpaw that would be subse- quently injected with CFA. Three to four days before the hindpaw CFA injection, ibotenic acid (200 nl, $10 \mu \mathrm{g} / \mu \mathrm{l}$ in aCSF; Tocris Bioscience) mixed with blue fluorescent beads (FluoSpheres, Invitrogen) at a 100:1 concentration was delivered into the $\mathrm{PB}$ (AP, $-1.2 \mathrm{~mm}$; ML, $-2.3 \mathrm{~mm}$; $\mathrm{DV},+3 \mathrm{~mm}$ from interaural line at a $14^{\circ}$ angle to the coronal plane). The lesion induced by ibotenic acid was assessed histologically using Nissl stain.

\section{Experimental design}

All studies used a within-subject design, comparing neuronal activity in a preblock period with that during PB block at various time points before and after the induction of localized inflammation in a single hindpaw.

For experiments testing the role of $\mathrm{PB}$ in naive animals, an $\mathrm{ON}-$ or OFF-cell was isolated and characterized. Baseline mechanical sensitivity was tested using Von Frey fibers $(26,60$, and $100 \mathrm{~g}$ ) applied in ascending order to the interdigital webbing of the hindpaw for a period of $8 \mathrm{~s}$. Withdrawal latencies were determined from hamstring EMG. Trials with no response were assigned a latency of $8 \mathrm{~s}$. Three trials were performed with each force, and a minimum of two testing sites was used in rotation. Individual trials were initiated at intervals of at least $30 \mathrm{~s}$, with longer interstimulus intervals (up to $4 \mathrm{~min}$ ) used when necessary to capture a period when the cell under study was active (OFF-cell) or inactive (ON-cell). Muscimol ( $200 \mathrm{nl}, 8 \mathrm{pmol})$ mixed with fluorescent beads $(1: 100)$ was microinjected into the lateral PB contralateral or ipsilateral to the stimulated paw (Roeder et al., 2016). Mechanical sensitivity testing was repeated as in baseline beginning 4 min after the injection was complete.

For experiments testing the role of $\mathrm{PB}$ in acute inflammation, an $\mathrm{ON}$ or OFF-cell was isolated, and baseline parameters were determined as above using 26, 60, and $100 \mathrm{~g}$ Von Frey fibers. CFA was then injected in the plantar surface of hindpaw. The animal was then left undisturbed for 10 min. Mechanical testing of the CFA-treated and untreated hindpaws was performed between 15 and $50 \mathrm{~min}$ following CFA injection. Muscimol was then injected in the $\mathrm{PB}$ contralateral to the CFA-treated hindpaw at $\sim 60$ min post-CFA administration. Mechanical sensitivity was assessed between 15 and $50 \mathrm{~min}$ after muscimol injection as described above.

For experiments testing the role of $\mathrm{PB}$ in persistent inflammation, CFA was injected into the hindpaw either $1 \mathrm{~d}$ or $5-6 \mathrm{~d}$ before the electrophys- 

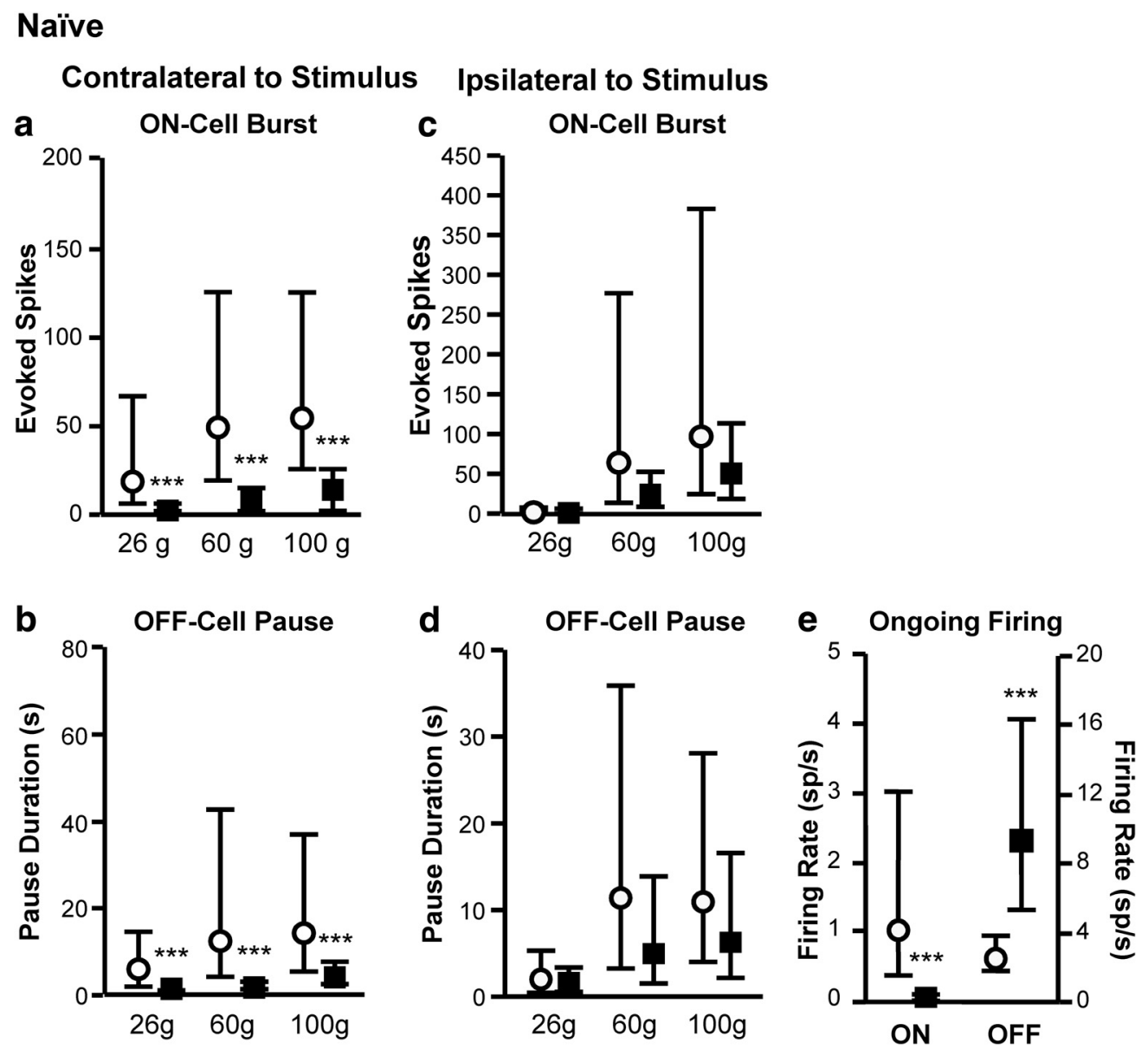

\section{O Pre-block \\ PB block}

Figure 4. Inactivation of PB interfered with the ON-cell burst and OFF-cell pause evoked by mechanical stimulation of the paw contralateral to the block in naive animals, with no effect on responses related to stimulation of the paw ipsilateral to block. $\boldsymbol{a}, 0 \mathrm{~N}$-cell burst/stimulation of paw contralateral to block. Effect of muscimol microinjected into the lateral $\mathrm{PB}$ contralateral to stimulated hindpaw on ON-cell activity associated with the application of Von Frey probes. Significant effects of block $\left(F_{(1,13)}=12.48, p=0.0037\right)$, and force $\left(F_{(2,26)}=13.99, p<0.0001\right)$, with no force $\times$ block interaction $\left(F_{(2,26)}=0.96, p=0.91, n=14\right.$ cells). $\boldsymbol{b}$, OFF-cell pause/stimulation of paw contralateral to block. Effect of muscimol microinjected into the lateral PB contralateral to stimulated hindpaw on OFF-cell pause. Significant effect of block $\left(F_{(1,11)}=13.86, p=0.0034\right)$ and force $\left(F_{(2,22)}=7.44, p=0.0034\right)$, with no block $\times$ force interaction $\left(F_{(2,22)}=3.02, p=0.07\right.$, $n=12$ cells with quantifiable pause across all forces). $c, 0 \mathrm{~N}$-cell burst/stimulation of paw ipsilateral to block. Effect of muscimol microinjected into the lateral PB ipsilateral to stimulated hindpaw on ON-cell activity associated with the application of Von Frey probes. Significant effect of force $\left(F_{(2,22)}=30.67, p<0.0001\right)$, but no effect of block $\left(F_{(1,11)}=1.27, p=0.28\right)$ or block $\times$ force interaction $\left(F_{(2,22)}=1.27, p=0.30, n=12\right)$. $\boldsymbol{d}$, OFF-cell pause/stimulation of paw ipsilateral to block. Effect of muscimol microinjected into the lateral PB ipsilateral to stimulated hindpaw on OFF-cell pause. Significant effect of force $\left(F_{(2,18)}=9.47, p=0.0015\right)$, but no effect of block $\left(F_{(1,9)}=2.87, p=0.12\right)$ or block $\times$ force interaction $\left(F_{(2,18)}=0.91, p=0.42, n=10\right.$ cells $) . e, 0$ ngoing firing of $\mathrm{ON}$-cells was suppressed, while that of OFF-cells was increased. Data for contralateral and ipsilateral block are combined, since there was no difference depending on the side (0N-cells: $t_{(25)}=6.78, p<0.001, n=26 ; 0$ FF-cells: $\left.t_{(23)}=5.72, p<0.001, n=24\right)$. Evoked activity was analyzed using a two-way ANOVA with repeated measures on both stimulus force and block as factors, with Sidak's multiple-comparisons test used to compare responses during block with preblock baseline at each force when the effect of block was significant. Spontaneous activity before block was compared with that during block using $t$ tests for correlated means. Cell data are presented as the geometric mean with $95 \%$ confidence intervals. ${ }^{* * *} p<0.001$ compared with preblock baseline. Sp/s, Spikes per second.

iological experiment. Following isolation and characterization of an RVM neuron, as above, baseline mechanical sensitivity and withdrawal latencies were determined for the two hindpaws with Von Frey fibers (4, $8,15,26,60$, and $100 \mathrm{~g}$ ) as described above. Muscimol was then microinjected into the PB contralateral or ipsilateral to the CFA-treated hindpaw (ipsilateral was tested for the 5-6 d time point, but not the $1 \mathrm{~d}$ time point). Mechanical sensitivity testing was then repeated, starting 4 min after completion of the injection.

\section{Histology}

Upon the conclusion of the recording experiment, an electrolytic lesion was made in the RVM to localize the recording site. Rats were overdosed with methohexital and perfused transcardially with saline followed by formalin. The brains were removed and sectioned on a Leica CM3050 S Cryostat (60 $\mu \mathrm{m}$ sections). The RVM lesion and fluorescent beads mark- ing the injection site in the PB were photographed with an Optronics Microfire Camera attached to an Olympus BX51 Microscope. If beads or lesion were not found, the data were not analyzed further. Injection sites were plotted on hand-drawn sketches of the sections in Adobe Illustrator using landmarks defined by Paxinos and Watson (2009). If injection sites were not located within the lateral parabrachial complex, the data were not analyzed further. The RVM was defined as the nucleus raphe magnus and adjacent reticular formation medial to the lateral boundary of the pyramids at the level of the facial nucleus.

\section{Analysis and statistics}

The microelectrode recording, EMG, and EKG output were digitized and collected using Spike2 software (Cambridge Electronics Design). Each spike waveform was sorted using Spike2 template matching and cluster analysis, verified on an individual spike basis. 
Nocifensive reflex-related neuronal activity was defined as the total number of spikes in each ON-cell burst and the duration of the OFF-cell pause. Although trials using Von Frey fibers were generally not initiated until ON-cells were inactive or OFF-cells were active, some ON-cells became active or OFF-cells became inactive for a prolonged period of time ( $>5 \mathrm{~min})$. For those cases where $\mathrm{ON}$-cells were continuously active, spike count during the $8 \mathrm{~s}$ Von Frey stimulation period was used. For OFF-cells that were inactive, a pause duration of $8 \mathrm{~s}$ was assigned.

Ongoing activity was defined as the average firing frequency $>30 \mathrm{~s}$ before heat trials or during the $30 \mathrm{~s}$ immediately before beginning the Von Frey stimulation protocol. A change in ongoing firing was defined as an increase or decrease of at least 50\% during PB block compared with preblock.

Withdrawal latencies and cell parameters following block of the parabrachial complex were compared with those in preblock baseline. Because cell data are typically highly skewed, parameters obtained before and during block were compared using log-transformed data, and were reported as the geometric mean with $95 \%$ confidence limits. Withdrawal thresholds and latencies are reported as the mean + SEM. Data were analyzed using repeated-measures ANOVA followed by Sidak's test for multiple comparisons or $t$ test for correlated means. For all tests, $p<0.05$ was considered to be significant.

\section{Results}

A total of $91 \mathrm{ON}$-cells and $81 \mathrm{OFF}$-cells were recorded in 153 animals. The injection of CFA into the plantar surface of the hindpaw produced localized inflammation that was evident within the first hour, with an increase in hindpaw thickness from $4.9 \pm 0.4 \mathrm{~mm}$ before the injection to $9.2 \pm 0.5 \mathrm{~mm}$ by $1 \mathrm{~h}$ postinjection, and $10.5 \pm 0.6 \mathrm{~mm}$ by the fifth day. This inflammation was accompanied by significant and prolonged behavioral hyperalgesia. Thus, the threshold for withdrawal of the CFA-treated hindpaw was reduced significantly compared with the untreated hindpaw at each of the three time points examined, as summarized in Figure 1. In the experiment performed during acute inflammation, we tested 26, 60, and $100 \mathrm{~g}$ fibers. Before CFA injection, only 2 of 24 animals responded to a $26 \mathrm{~g}$ fiber, whereas all responded to 60 and $100 \mathrm{~g}$. We therefore considered 60 and $100 \mathrm{~g}$ stimuli to be "noxious" for subsequent analysis. Following the injection of CFA, all animals responded to the $26 \mathrm{~g}$ fiber, demonstrating the development of mechanical hyperalgesia. In experiments testing prolonged inflammation ( 1 or $5-6 \mathrm{~d}$ postCFA administration), we tested 4, 8, 15, 26, 60, and 100 g fibers. In all cases, the withdrawal of the CFA-treated hindpaw was elicited at $\leq 15$ g. For comparison, the threshold for the untreated hindpaw was $60 \mathrm{~g}$ in most cases ( 15 of 18 animals tested at $1 \mathrm{~d}$ post-CFA administration, and 21 of 23 animals at 5- 6 d postCFA administration).

\section{Effect of blocking PB in naive animals}

We first considered the effect of blocking $\mathrm{PB}$ contralateral or ipsilateral to hindpaw stimulation on the ON-cell burst and OFFcell pause in naive animals, because spinoparabrachial neurons project to both contralateral and ipsilateral $\mathrm{PB}$, although the contralateral projection is significantly stronger (Todd et al., 2000). A schematic of the experiment is shown in Figure $2 a$, and the locations of microinjection sites are plotted in Figure $2 b$.

PB block contralateral to the stimulus site resulted in a small but statistically significant increase in the latency to withdraw the hindpaw from noxious (60 and $100 \mathrm{~g}$ ) stimuli (Fig. 2c), consistent with a previous report of modest hypoalgesia with block of $\mathrm{PB}$ contralateral to an acute noxious stimulus (Roeder et al., 2016). By contrast, the latency for withdrawal of the paw ipsilateral to the PB block was slightly but significantly reduced, although only with the $26 \mathrm{~g}$ fiber (Fig. $2 d$ ).

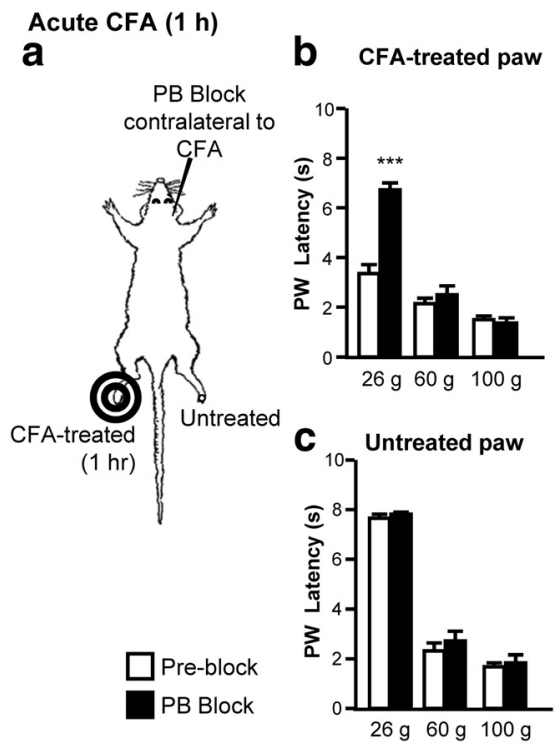

Figure 5. Inactivation of lateral PB contralateral to an acutely inflamed paw attenuated hyperalgesia, with no effect on responses evoked by stimulation of the untreated paw ipsilateral to the block. $\boldsymbol{a}$, Schematic of experimental setup with PB block contralateral to an acutely inflamed paw ( $\sim 1 \mathrm{~h}$ following (FA injection). Stimulation was delivered to the inflamed paw (contralateral to block) and to the untreated paw (ipsilateral to block). $\boldsymbol{b}$, Withdrawal latency for inflamed paw before and during block of PB contralateral to the inflammation. The latency to respond to the $26 \mathrm{~g}$ fiber was significantly prolonged. There was a significant effect of block $\left(F_{(1,23)}=31.4, p<0.0001\right)$, force $\left(F_{(2,46)}=156.4, p<0.0001\right)$, and block $\times$ force interaction $\left(F_{(2,46)}=31.2, p<0.0001\right)$.c, Withdrawal latency for untreated paw before and during block of $\mathrm{PB}$ contralateral to the inflammation (ipsilateral to the stimulated paw). There was a significant effect of force $\left(F_{(2,46)}=358.8, p<0.0001\right)$, but no effect of block $\left(F_{(1,23)}=2.7, p=\right.$ $0.116)$ or block $\times$ force interaction $\left(F_{(2,46)}=0.27, p=0.76\right)$. Two-way ANOVA with repeated measures on force and block, followed by Sidak's test for multiple comparisons when the effect of block was significant. Values are the mean + SEM. ${ }^{* * *} p<0.001$ compared with preblock, $n=24$.

Effects of PB block on the ON-cell burst and OFF-cell pause paralleled the effects on behavior. Both the ON-cell burst and OFF-cell pause evoked by stimulation of the paw contralateral to $\mathrm{PB}$ block were significantly reduced, as shown in the examples in Figure 3 and summarized in Figure 4, $a$ and $b$. By contrast, the reflex-related firing of a separate set of $\mathrm{ON}$ - and OFF-cells evoked by stimulation of the hindpaw ipsilateral to the PB block was unchanged (Fig. $4 c, d$ ). The ongoing firing of both $\mathrm{ON}$ - and OFFcells was altered in both groups (Fig. 4e). All of the ON-cells tested displayed decreased ongoing firing during $\mathrm{PB}$ block, and all OFF-cells showed increased firing.

This set of experiments in naive animals therefore replicated our earlier report that $\mathrm{PB}$ contralateral to the stimulation site relays information to pain-modulating neurons in the RVM and also contributes to the behavioral response to the stimulus. These experiments also confirmed that acute nociceptive information is not relayed through the ipsilateral PB (Roeder et al., 2016).

\section{Effect of blocking PB contralateral to the acutely inflamed hindpaw}

In the second set of experiments, we sought to determine whether contralateral $\mathrm{PB}$ also relayed information in the context of acute inflammation. We therefore tested the effect of blocking PB contralateral to an acutely inflamed hindpaw on behavioral and neuronal responses evoked by stimulation of the inflamed paw and of the untreated paw (with the latter ipsilateral to the block). A 

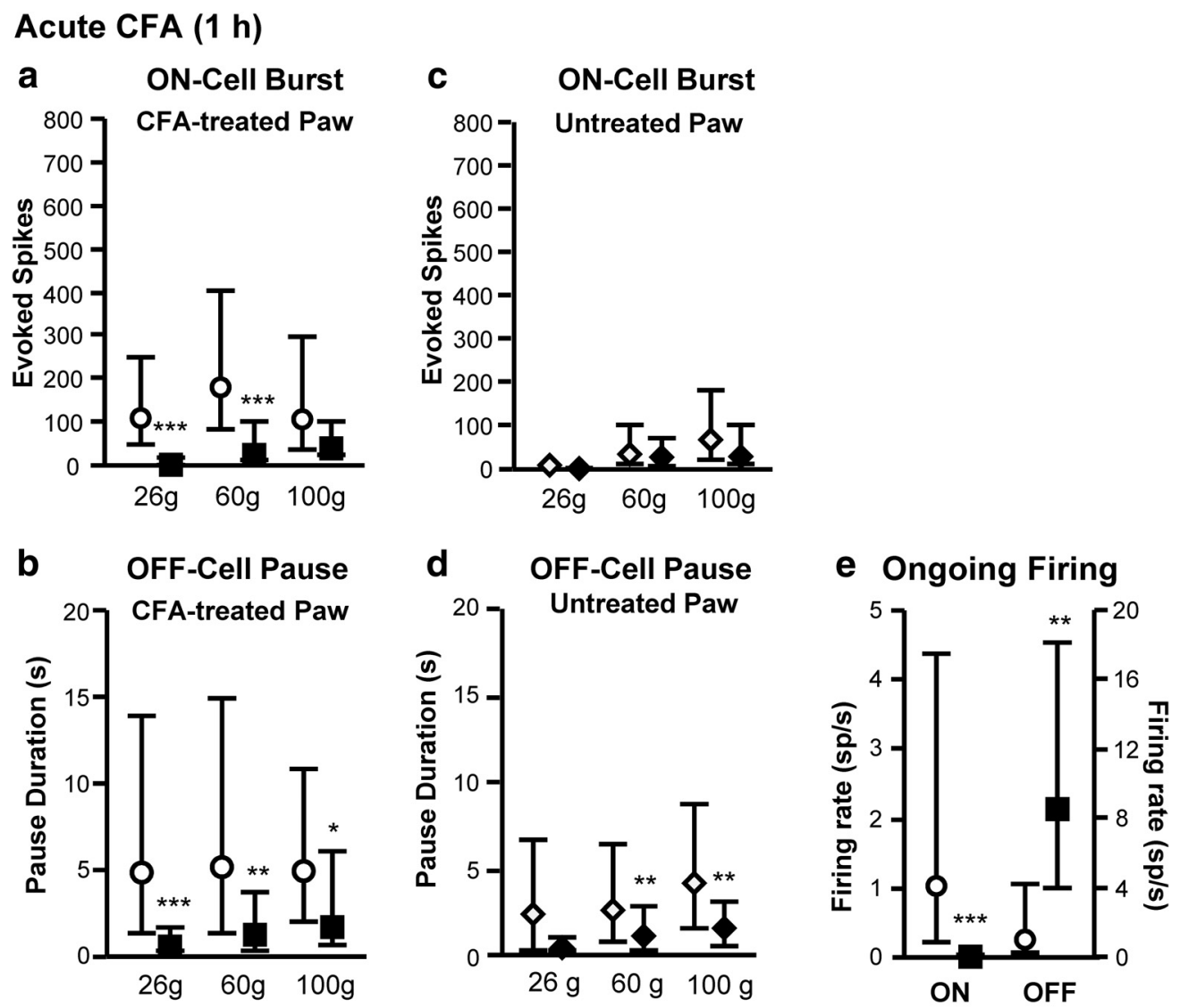

\section{O $\diamond$ Pre-block \\ $\square$ PB block}

Figure 6. Inactivation of $\mathrm{PB}$ contralateral to an acutely inflamed paw interfered with the $\mathrm{ON}$-cell burst and $\mathrm{OFF}$-cell pause evoked by mechanical stimulation of that paw. $\boldsymbol{a}, 0 \mathrm{~N}$-cell burst/inflamed paw. Effect of muscimol microinjected into the lateral PB contralateral to stimulated (inflamed) hindpaw on ON-cell activity associated with the application of Von Frey probes. Significant effects of $\operatorname{block}\left(F_{(1,11)}=12.55, p=0.0046\right)$ and force $\left(F_{(2,22)}=13.59, p=0.0001\right)$, and block $\times$ force interaction $\left(F_{(2,22)}=8.23, p=0.0021 ; n=12\right.$ cells $)$. $\boldsymbol{b}, 0$. OFF-cell pause/inflamed paw. Effect of muscimol microinjected into the lateral PB contralateral to stimulated (inflamed) hindpaw on OFF-cell pause. Significant effect of block $\left(F_{(1,11)}=9.58, p=0.010\right)$, no effect of force $\left(F_{(2,22)}=1.19\right.$, $p=0.3241)$, or block $\times$ force interaction $\left(F_{(2,22)}=1.15, p=0.33 ; n=12\right.$ cells with quantifiable pause across all forces). $c, 0$ N-cell burst/untreated paw. Effect of muscimol microinjected into the lateral PB ipsilateral to stimulated (untreated) hindpaw on ON-cell activity associated with application of Von Frey probes. Significant effect of force $\left(F_{(2,22)}=29.95, p<0.0001\right)$, but no effect of $\operatorname{block}\left(F_{(1,11)}=1.96, p=0.19\right)$ or block $\times$ force interaction $\left(F_{(2,2)}=0.14, p=0.87, n=12\right.$ cells). $\boldsymbol{d}$, OFF-cell pause/ipsilateral block. Effect of muscimol microinjected into the lateral PB ipsilateral to stimulated (untreated) hindpaw on OFF-cell pause. Significant effect of block $\left(F_{(1,11)}=8.93, p=0.012\right)$ and force $\left(F_{(2,22)}=5.00, p=0.016\right)$, with no block $\times$ force interaction $\left(F_{(2,22)}=0.93\right.$, $p=0.41 ; n=12$ cells with quantifiable pause at all forces). $\boldsymbol{e}$, Ongoing firing of $0 \mathrm{~N}$-cells was suppressed while that of OFF-cells was increased, comparable to what was seen in naive animals. (ON-cells: $t_{(11)}=4.78, p=0.0006, n=12 ;$ OFF-cells: $t_{(12)}=3.22, p=0.0074, n=13$ ). Evoked activity was analyzed using a two-way ANOVA with repeated measures on both stimulus force and block as factors, with Sidak's multiple-comparisons test used to compare responses during block with preblock baseline at each force when the effect of block was significant. Spontaneous activity

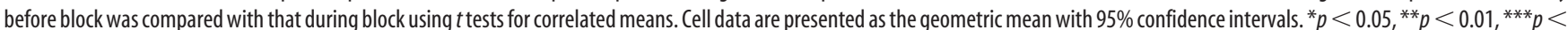
0.001 compared with preblock. Sp/s, Spikes per second.

schematic of the experimental setup is shown in Figure $5 a$. Behavioral and neuronal responses to Von Frey stimulation were assessed $\sim 1 \mathrm{~h}$ after CFA injection.

As already described, acute inflammation produced hyperalgesia in the CFA-injected hindpaw compared with baseline, with a reduction in threshold (Fig. 1). Hyperalgesia was also manifest in a significant reduction in the latency to respond to 26 and $60 \mathrm{~g}$ fibers [data not shown; two-way ANOVA followed by Sidak's post hoc test revealed a significant effect of CFA compared with preCFA baseline $\left(F_{(1,23)}=290.1, p<0.0001\right)$, a significant effect of force $\left(F_{(2,46)}=298.1, p<0.0001\right)$, and a significant CFA $\times$ force interaction $\left.\left(F_{(2,46)}=119.2, p<0.0001\right)\right]$. As shown in Figure $5 b$, blocking PB contralateral to the acutely inflamed hindpaw had an antihyperalgesic effect, returning the latency to respond to the $26 \mathrm{~g}$ fiber to values typically seen with the stimulation of unin- flamed paws. Responses to stimulation of the untreated hindpaw (ipsilateral to the PB block) were unaffected by PB block (Fig. 5c).

Blocking PB contralateral to the acutely inflamed hindpaw also significantly attenuated reflex-related changes in the firing of $\mathrm{ON}$ - and OFF-cells associated with the stimulation of this paw (Fig. $6 a, b$ ), with the strongest effects at 26 and $60 \mathrm{~g}$, paralleling the behavioral effects of contralateral PB block.

The ON-cell burst associated with stimulation of the untreated hindpaw, ipsilateral to the block, was unchanged during the $\mathrm{PB}$ block (Fig. 6c), comparable to what was seen in naive animals. However, the duration of the OFF-cell pause evoked by stimulation of the untreated paw was significantly reduced, which contrasts with the lack of effect of ipsilateral block in naive animals (Fig. 6d).

Finally, the ongoing firing rate of ON- and OFF-cells was altered, with a decrease in ON-cell firing and an increase in OFF- 
cell firing (Fig. 6e), an effect again comparable to what was seen in naive animals. All OFF-cells recorded showed an increase in ongoing activity compared with preblock baseline, and 9 of $10 \mathrm{ON}$-cells with ongoing firing in baseline showed a decrease in ongoing activity during $\mathrm{PB}$ block.

This set of experiments in animals subjected to acute inflammation showed that, as in naive animals, $\mathrm{PB}$ contralateral to the stimulation site is the principal relay of information to pain-modulating neurons in RVM and contributes to the behavioral response to the stimulus. However, there is a suggestion that PB ipsilateral to the peripheral stimulus is recruited in these animals with developing inflammation.

\section{Effect of blocking PB contralateral to the inflamed hindpaw in persistent inflammation}

In the third set of experiments, we extended the studies in acute inflammation to persistent inflammation. We therefore tested the effect of blocking PB contralateral to an inflamed hindpaw on behavioral and neuronal responses evoked by stimulation of the inflamed paw and of the untreated paw. A schematic of the experimental setup is shown in Figure $7 a$. Animals were treated with CFA $1 \mathrm{~d}$ or 5-6 $\mathrm{d}$ before the recording session.

In contrast to the antihyperalgesic effect of contralateral PB block in the first hour following CFA injection reported above (Fig. 5b), blocking PB contralateral to the inflamed hindpaw at 1 or $5-6 \mathrm{~d}$ postinjection did not reverse the hypersensitivity of the inflamed hindpaw (Fig. $7 b, d$ ). Moreover, this block contralateral to the inflamed hindpaw led to hyperalgesia (i.e., a decreased latency to respond) in the untreated hindpaw, ipsilateral to the PB block (Fig. $7 c, e$ ), an effect similar to that seen in the naive animals.

The effect of blocking PB contralateral to the inflamed paw on RVM neuronal activity was reduced at these time points compared with its effects in naive animals or animals subjected to acute inflammation. In fact, blocking PB contralateral to the inflamed hindpaw at the $1 \mathrm{~d}$ time point had no effect on the evoked responses of either ON- or OFF-cells. Summary data are shown in Figure 8, $a$ and $b$, with the total response summed across the innocuous (4, 8, and $15 \mathrm{~g}$ ) and noxious (60 and $100 \mathrm{~g}$ ) ranges for stimulation of the CFA-treated and untreated paws. The ongoing firing of both $\mathrm{ON}$ - and OFF-cells exhibited considerable variability in response to $\mathrm{PB}$ blockade in animals at $1 \mathrm{~d}$ postCFA administration. OFF-cell firing was not significantly changed following PB block after $1 \mathrm{~d}$ of inflammation, and only 3 of 10 OFF-cells sampled showed an increase in firing rate; the remaining 7 exhibited decreased or no change in firing. Although ON-cells overall showed a statistically significant decrease in ongoing activity compared with preblock baseline, only 9 of the 14 cells with ongoing activity showed a decrease in firing, and 2 cells showed an increase in activity ( 3 cells without ongoing activity remained silent during $\mathrm{PB}$ block). These data are summarized in Figure $8 c$.

By 5-6 d after injection of CFA, ON- and OFF-cells showed differential responses to $\mathrm{PB}$ block. For ON-cells, similar to what was seen $1 \mathrm{~d}$ post-CFA administration, blocking contralateral $\mathrm{PB}$ at 5-6 d post-CFA administration failed to alter the ON-cell burst associated with stimulation of either the inflamed (contralateral to PB block) or uninflamed (ipsilateral to PB block) hindpaw (Fig. 8d). The OFF-cell pause associated with both innocuous and noxious stimulation of the inflamed hindpaw was significantly attenuated (Fig. 8e).

At $5-6 \mathrm{~d}$ post-CFA administration, the ongoing firing of both $\mathrm{ON}$ - and OFF-cells was not altered in a uniform way by blocking $\mathrm{PB}$ contralateral to the inflamed paw (Fig. $8 f$ ). Eight of $13 \mathrm{ON}$ cells showed either decreased or unchanged activity with $\mathrm{PB}$ block, and 5 ON-cells showed an increase. OFF-cells showed an even greater variety of responses, with 5 of 10 OFF-cells increasing their ongoing firing, and 5 OFF-cells decreasing or remaining unchanged.

These experiments in animals subjected to persistent inflammation indicate that $\mathrm{PB}$ contralateral to the inflamed site loses its status as the main relay of information relevant to nocifensive behaviors and recruitment of RVM pain-modulating neurons. 


\section{CFA (1 or 5-6 d, block contralateral to CFA)}

a ON-Cell Burst, $1 \mathrm{~d}$

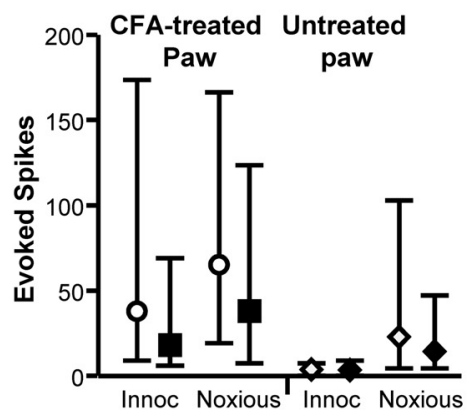

d

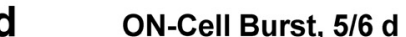

CFA-treated Untreated

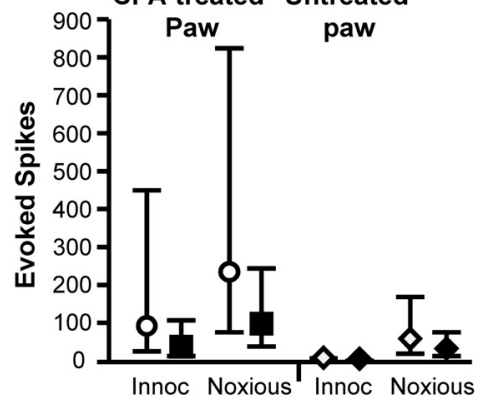

$O \diamond$ Pre-block
$\square$ PB block b OFF-Cell Pause, $1 \mathrm{~d}$

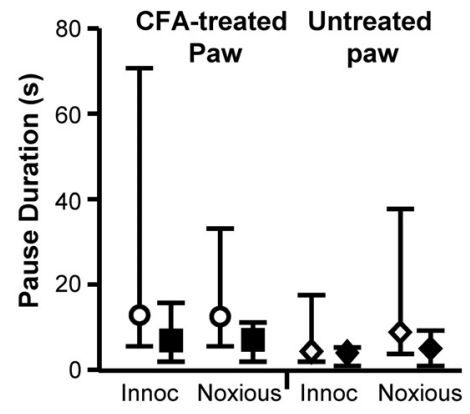

e OFF-Cell Pause, $5 / 6 \mathrm{~d}$

CFA-treated Untreated

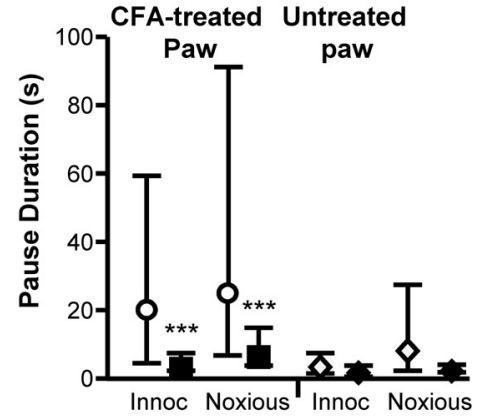

C Ongoing Firing, $1 \mathrm{~d}$

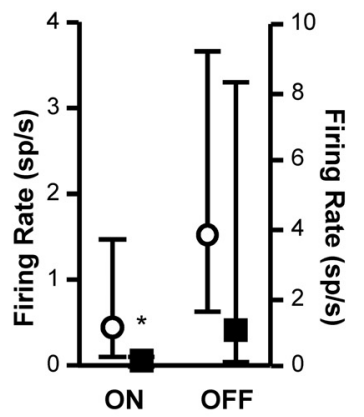

f Ongoing Firing, 5/6 d

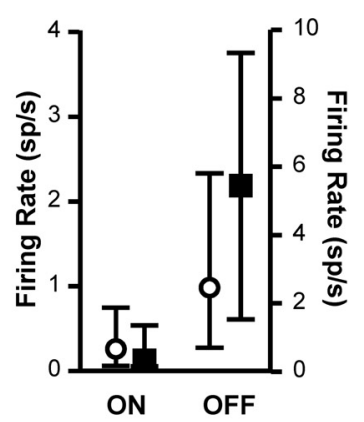

Figure 8. Inactivation of lateral PB contralateral to an inflamed paw (1 or $5 / 6 \mathrm{~d}$ ) did not attenuate the $0 \mathrm{~N}$-cell burst evoked by mechanical stimulation of the inflamed or untreated paw. $\boldsymbol{a}, 0 \mathrm{~N}$-cell burst/inflamed paw, $1 \mathrm{~d}$ post-CFA administration. Effect of muscimol microinjected into the lateral PB contralateral to stimulated (inflamed) hindpaw on ON-cell activity associated with application of Von Frey probes in the innocuous ( 4,8 , and $15 \mathrm{~g}$ probes) and noxious ( 60 and $100 \mathrm{~g}$ probes) ranges to the inflamed and untreated paws. For the inflamed paw, there was a significant effect of force (innocuous vs noxious, $\left.F_{(1,13)}=8.74, p=0.011\right)$, but no effect of block $\left(F_{(1,13)}=0.081, p=0.38\right)$ or force $\times$ block interaction $\left(F_{(1,13)}=0.12, p=0.73\right)$. For the untreated paw, ipsilateral to the block, there was a significant effect of force $\left(F_{(1,13)}=14.06, p=0.0024\right)$, but no effect of block $\left(F_{(1,13)}=1.19, p=0.29\right)$ or force $\times$ block interaction $\left(F_{(1,13)}=0.045, p=0.83, n=14\right) \cdot \boldsymbol{b}, 0 \mathrm{FF}-\mathrm{cell}$ pause/inflamed paw, $1 \mathrm{~d}$ post-CFA administration. Effect of muscimol microinjected into the lateral PB contralateral to stimulated (inflamed) hindpaw on OFF-cell pause associated with application of innocuous and noxious Von Frey probes to the inflamed and untreated paws. For the inflamed paw (contralateral to block, 7 cells with full datasets), there was no effect of force $\left(F_{(1,6)}=1.18, p=\right.$ 0.32 ) or block $\left(F_{(1,6)}=1.11, p=0.33\right)$. Similarly, for the normal paw (ipsilateral to block, eight cells with full datasets), there was no effect of force $\left(F_{(1,7)}=0.00006, p=0.99\right)$ or block $\left(F_{(1,17)}=\right.$ $0.34, p=0.86)$. c, Ongoing firing of both cell classes was unchanged during PB block $1 \mathrm{~d}$ post-CFA administration. (ON-cells: $t_{(13)}=2.44, p=0.030, n=14 ; 0 \mathrm{FF}$-cells: $t_{(9)}=1.56, p=0.15$, $n=10) . \boldsymbol{d}, 0 \mathrm{~N}$-cell burst/inflamed paw, $5-6 \mathrm{~d}$ post-CFA administration. Effect of muscimol microinjected into the lateral PB contralateral to stimulated (inflamed) hindpaw on $0 \mathrm{~N}$-cell activity associated with the application of $V$ on Frey probes in the innocuous and noxious ranges to the inflamed and untreated paws. For the inflamed paw, there was a significant effect of force (innocuous vs noxious, $\left.F_{(1,12)}=57.89, p<0.0001\right)$, but no effect of block $\left(F_{(1,12)}=3.11, p=0.1030\right)$ or force $\times$ block interaction $\left(F_{(1,12)}=0.12, p=0.73\right)$. For the normal paw, ipsilateral to the block, there was a significant effect of force $\left(F_{(1,12)}=42.22, p<0.0001\right)$, but no effect of block $\left(F_{(1,12)}=1.94, p=0.19\right)$ or force $\times$ block interaction $\left(F_{(1,12)}=0.034, p=0.86, n=13\right)$. $e, 0$ FF-cell pause/inflamed paw, 5- $6 \mathrm{~d}$ post-CFA. Effect of muscimol microinjected into the lateral PB contralateral to stimulated (inflamed) hindpaw on 0FF-cell pause associated with application of innocuous and noxious Von Frey probes to the inflamed and untreated paws. For the inflamed paw $(n=11)$, there was a significant effect of force (innocuous vs noxious, $\left.F_{(1,10)}=6.79, p=0.026\right)$ and block $\left(F_{(1,10)}=7.93, p=0.018\right)$, with no force $\times$ block interaction $\left(F_{(1,10)}=1.6, p=0.23\right)$. For the normal paw, ipsilateral to the block ( $n=10$ cells with complete datasets), there was no effect of force $\left(F_{(1,9)}=1.12, p=0.32\right)$ or block $\left(F_{(1,9)}=4.29, p=0.068\right) . f$, Ongoing firing of both cell classes was unchanged during PB block $5-6$ d post-CFA administration (0N-cells: $t_{(12)}=0.72, p=0.49$, $n=13 ;$ OFF-cells: $\left.t_{(10)}=1.51, p=0.16, n=11\right)$. Evoked activity was analyzed using a two-way ANOVA with repeated measures on both stimulus force and block as factors, with Sidak's multiplecomparisons test used to compare responses during block with preblock baseline at each force when effect of block was significant. Spontaneous activity before block was compared with that during block using $t$ tests for correlated means. Cell data are presented as the geometric mean with $95 \%$ confidence intervals. ${ }^{*} p<0.05,{ }^{* * *} p<0.001$ compared with preblock. Sp/s, Spikes per second; Innoc, Innocuous.

Recruitment of PB ipsilateral to persistent inflammation

NK1-expressing neurons, presumed to represent the spinoparabrachial system, have been shown to play an important role in heightened behavioral responsiveness in inflammation (Nichols et al., 1999; Suzuki et al., 2002; Khasabov et al., 2005; Rivat et al., 2009), yet the previous set of experiments showed that the inactivation of PB contralateral to the inflammation site had limited effects on RVM neuronal activity and did not reverse behavioral hyperalgesia in persistent inflammation. The fourth set of experiments therefore explored the role of PB ipsilateral to the site of inflammation.
CFA was injected 5-6 d before the recording study in this set of experiments. The activity of an RVM neuron and withdrawal latencies of both the inflamed and untreated hindpaw were recorded before and after inactivation of the PB ipsilateral to the inflamed hindpaw (Fig. $9 a$, schematic). Injection sites in the PB area are shown in Figure $9 b$.

Blocking PB ipsilateral to the site of inflammation resulted in a significant increase in latencies for nociceptive withdrawals of both the inflamed and untreated hindpaws. The latency for withdrawal of the inflamed hindpaw was increased throughout the subnoxious range, demonstrating a net antihyperalgesic effect of re- 


\section{CFA (5-6 d, block ipsilateral to CFA)}

a

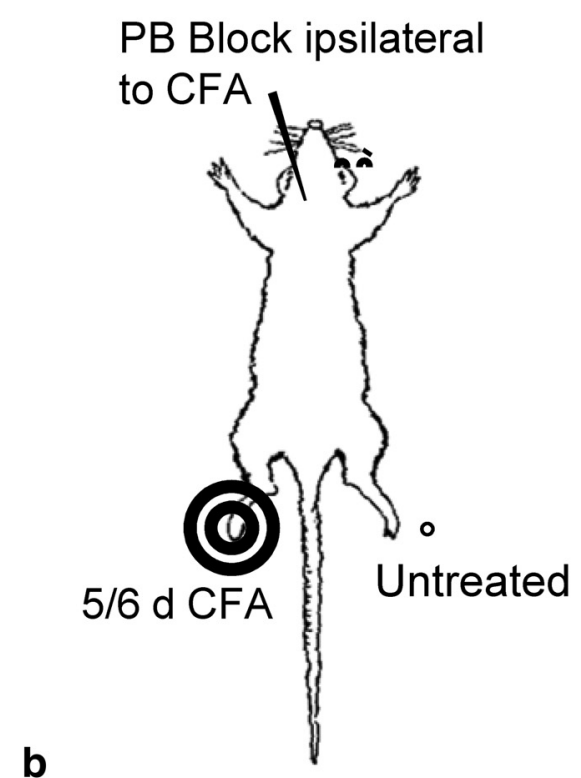

\section{$-0.60$}

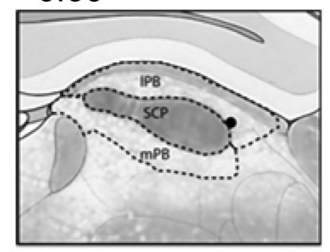

$-0.36$

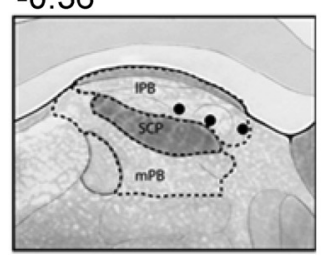

$-0.24$

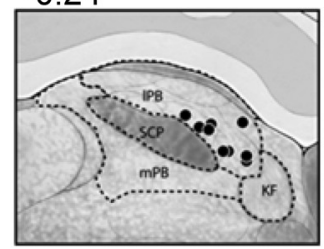

c

CFA-treated Paw
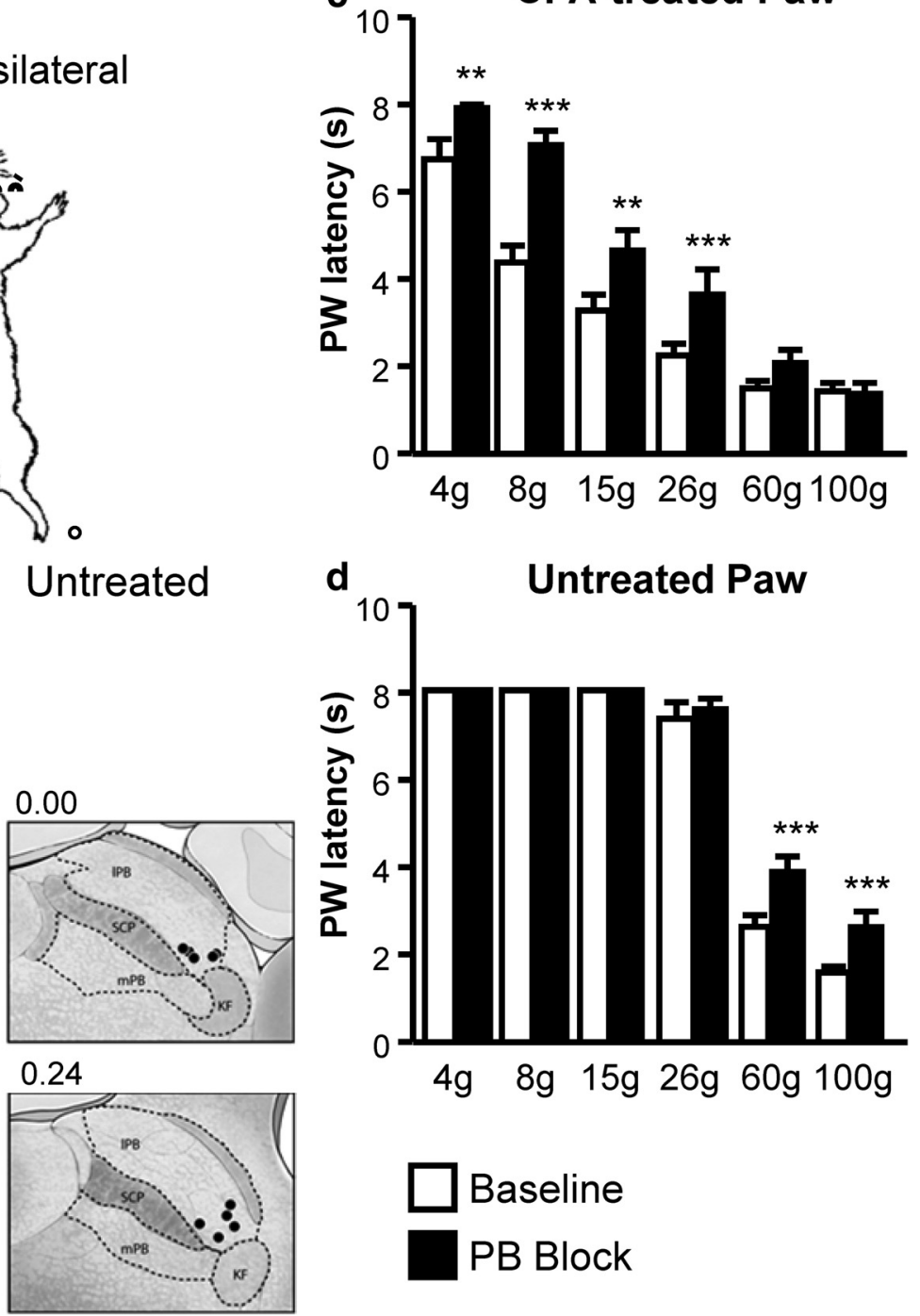

0.24
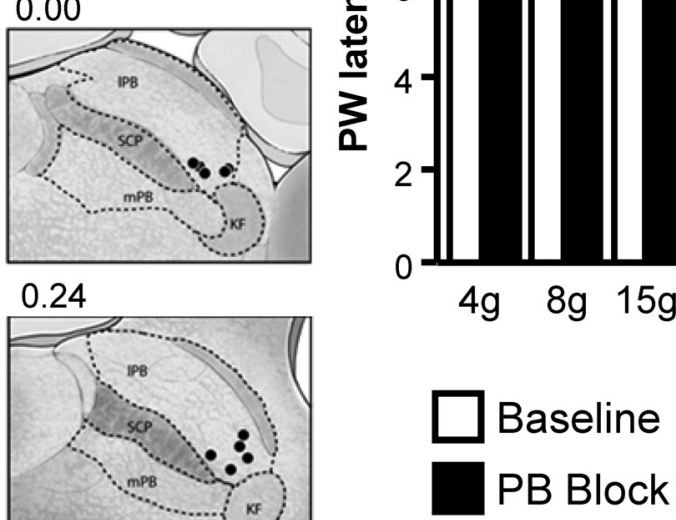

Figure 9. Inactivation of lateral PB ipsilateral to an inflamed paw (5-6 d) attenuated hyperalgesia in the inflamed paw and produced hypoalgesia in the untreated paw (contralateral to the block). $\boldsymbol{a}$, Schematic of the experimental setup with PB block ipsilateral to the inflamed paw. Stimulation was delivered to the inflamed paw (ipsilateral to block) and to the untreated paw (contralateral to block). $\boldsymbol{b}$, Locations of microinjection sites in the lateral PB complex ipsilateral to CFA-treated paw. Parabrachial injections were distributed among sections at +0.24 to -0.60 mm relative to the interaural line. Injections inside the lateral PB (IPB) region were considered on-target. KF, Kölliker-Fuse; mPB, medial parabrachial area; scp, superior cerebellar peduncle. $c$, Withdrawal latency for inflamed paw before and during block of PB. Latencies for responses to innocuous stimuli were significantly prolonged. There was a significant effect of force $\left(F_{(5,110)}=131.6\right.$, $p<0.0001)$, block $\left(F_{(1,22)}=56.4, p<0.0001\right)$, and force $\times$ block interaction $\left(F_{(5,110)}=6.2, p<0.0001\right)$. $d$, Withdrawal latency for untreated paw before and during block of PB. Latency for responses to noxious stimuli were significantly prolonged. There was a significant effect of force $\left(F_{(5,110)}=252.3, p<0.0001\right)$, block $\left(F_{(1,22)}=28.55, p<0.0001\right)$, and force $\times$ block interaction $\left(F_{(5,110)}=6.98, p<0.0001\right)$. Two-way ANOVA with repeated measures on force and block, followed by Sidak's test for multiple comparisons when the effect of block was significant. Value are the mean + SEM. ${ }^{* *} p<0.01,{ }^{* * *} p<0.001$ compared with preblock; $n=23$.

moving PB ipsilateral to the inflammatory insult (Fig. 9c). For the untreated hindpaw, where withdrawal was reliably elicited only in the noxious range, this block resulted in hypoalgesia (Fig. 9d).

Blocking PB ipsilateral to the inflammation site also significantly reduced the ON-cell burst and OFF-cell pause associated with Von Frey stimulation, an effect seen with stimulation of both the CFA-treated (ipsilateral to block) and untreated (contralateral to block) hindpaws in the innocuous (4-15 g) as well as noxious (60 and $100 \mathrm{~g}$ ) ranges (Fig. 10a,b). Ipsilateral PB block also significantly altered the ongoing firing of both $\mathrm{ON}$ - and 

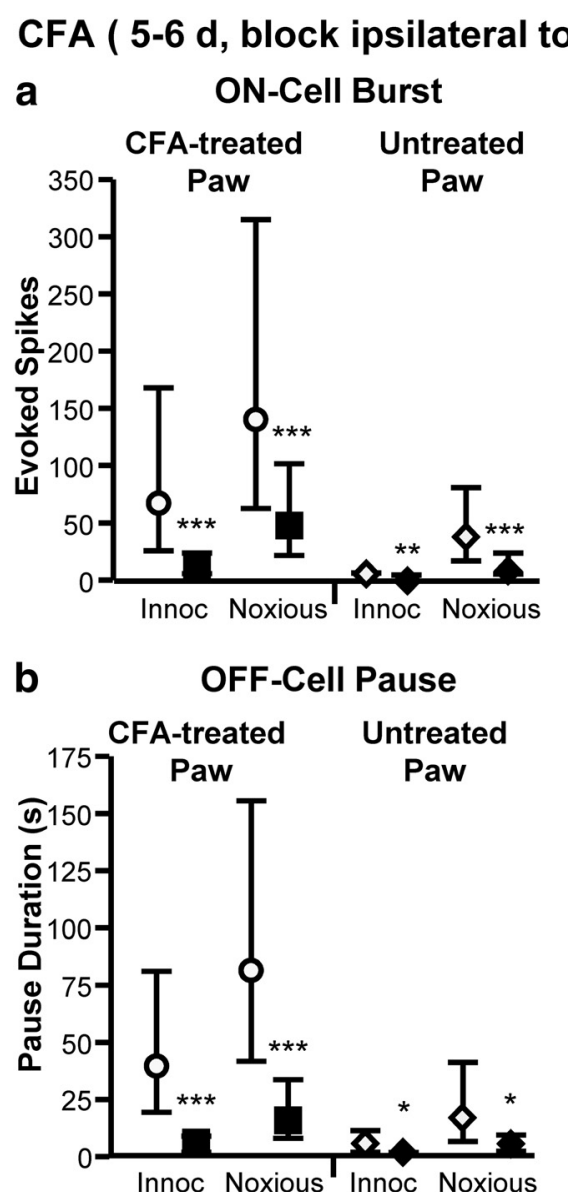

\section{Ongoing Firing}

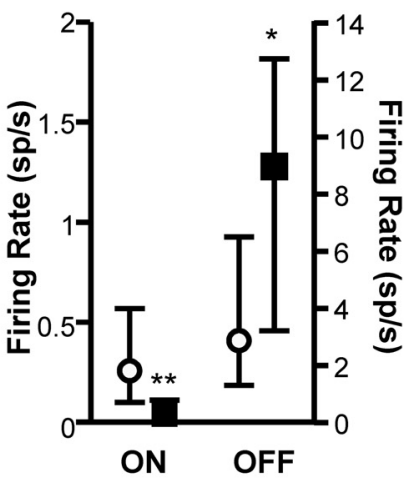

\section{O $\diamond$ Pre-block $\square$ PB block}

Figure 10. Inactivation of lateral PB ipsilateral to a paw subjected to persistent inflammation (5- $6 \mathrm{~d}$ ) attenuated the $0 \mathrm{~N}$-cell burst and OFF-cell pause evoked by mechanical stimulation of the inflamed and untreated paws. $\boldsymbol{a}, 0 \mathrm{~N}$-cell burst. Effect of PB block on ON-cell activity associated with the application of Von Frey probes in the innocuous and noxious ranges to the inflamed (ipsilateral to block) and untreated (contralateral to block). For stimulation of the inflamed paw, there was a significant effect of block $\left(F_{(1,15)}=13.22, p=0.0024\right)$, force (innocuous vs noxious, $F_{(1,15)}=45.71, p<0.0001$ ), and force $\times$ block interaction $\left(F_{(1,15)}=6.51, p=0.022\right)$. For stimulation of the normal paw, there was also a significant effect of block $\left(F_{(1,15)}=7.47, p=\right.$ 0.015 ) and force (innocuous vs noxious, $F_{(1,15)}=44.84, p<0.0001$ ), with no significant force $\times$ block interaction $\left(F_{(1,15)}=1.03\right.$, $p=0.32, n=16) \cdot \boldsymbol{b}$, OFF-cell pause. Effect of PB block on OFF-cell pause associated with the application of Von Frey probes in the innocuous and noxious ranges to the inflamed (ipsilateral to block) and untreated (contralateral to block) paws. For stimulation of the inflamed paw, there was a significant effect of block $\left(F_{(1,12)}=23.46, p=0.0004\right)$ and force (innocuous vs noxious, $F_{(1,12)}=$ $36.57, p<0.0001)$, with no force $\times$ block interaction $\left(F_{(1,13)}=3.29, p=0.95\right)$. For the normal paw, ipsilateral to the block, there was also a significant effect of block $\left(F_{(1,12)}=16.72, p=0.0015\right)$ and force $\left(F_{(1,12)}=8.70, p=0.012\right)$, with no force $\times$ block interaction $\left(F_{(1,12)}=0.0072, p=0.93, n=13\right) . c$, Ongoing firing of $0 \mathrm{~N}$-cells was suppressed while that of $0 \mathrm{FF}$-cells was increased (ON-cells: $t_{(15)}=3.61, p=0.003, n=16 ; 0 \mathrm{FF}-$ cells: $t_{(12)}=2.39, p=0.034, n=13$ ). Evoked activity was analyzed using a two-way ANOVA with repeated measures on both stimulus force and block as factors, with Sidak's multiple-comparisons test used to compare responses during block with preblock baseline at each force when the effect of block was significant. Spontaneous activity before block was compared with that during block using $t$ tests for correlated means. Cell data presented as the geometric mean with $95 \%$ confidence intervals. ${ }^{*} p<0.05,{ }^{* *} p<0.01,{ }^{* * *} p<0.001$ compared with preblock. Sp/s, Spikes per second; Innoc, Innocuous.

OFF-cells in these animals, with a decrease in ON-cell firing and an increase in OFF-cell firing (Fig. 10c).

This fourth set of experiments indicates that PB ipsilateral to persistently inflamed tissue contributes to the behavioral withdrawal and responses of RVM ON- and OFF-cells to both noxious and innocuous stimuli delivered to either paw. Persistent inflammation thus recruits or unmasks a net pronociceptive outflow from the ipsilateral $\mathrm{PB}$.
Recruitment of ipsilateral PB in persistent inflammation requires contralateral PB

Given the observations showing that the ipsilateral and contralateral PB are differentially recruited under basal conditions, and in acute versus persistent inflammation, the fifth set of experiments was designed to investigate the process by which the PB ipsilateral to the site of injury is called into play to influence the RVM in persistent inflammation. Since the contralateral $\mathrm{PB}$ is a major relay to the RVM both in normal animals and in those with acute inflammation, we hypothesized that the contralateral $\mathrm{PB}$ is required for the recruitment of ipsilateral PB during persistent inflammation. To test this, animals were subjected to an excitotoxic lesion of the left PB 3-4 d before the induction of inflammation of the contralateral hindpaw (Fig. 11a, schematic). Recording experiments took place 5-6 d after CFA injection, with acute block of the remaining PB ipsilateral to the inflamed paw.

The sites of ibotenic acid injection and examples of excitotoxic effects are shown in Figure $11, b, e$ and $f$.

Development of mechanical allodynia was eliminated in animals in which the contralateral PB had been lesioned before the induction of inflammation, with no difference in baseline withdrawal latencies between the CFA-treated and untreated hindpaws before acute block of the remaining $\mathrm{PB}$ (which was ipsilateral to the inflamed paw, $F_{(1,16)}=2.86, p=0.11, n=$ 17; Figs. $11 c, d$, baseline latencies). However, acute block of the remaining PB led to significant hyperalgesia in the CFAtreated hindpaw, with no change in the untreated hindpaw (Fig. 11c,d).

ON- and OFF-cells are typically "sensitized" in persistent inflammation (Cleary and Heinricher, 2013), with enhancement of the ON-cell burst and OFFcell pause evoked by stimulation of the inflamed paw compared with stimulation of the untreated paw. However, in animals in which PB contralateral to the inflammatory stimulus was lesioned before the injection of CFA, there was no difference in the ON-cell burst or OFF-cell pause evoked by innocuous stimulation of the CFA-treated versus untreated paw (ON-cell: $t_{(9)}=0.41, p=0.69, n=10$; OFF-cell: $t_{(9)}=0.91, p=$ $0.39, n=10)$. Further, blocking the remaining $\mathrm{PB}$ in these animals also had no effect on the ON-cell burst or OFF-cell pause evoked by the stimulation of either the inflamed hindpaw (ipsilateral to the acute block) or the untreated hindpaw (contralateral to the acute block), regardless of stimulus intensity (Fig. 12a,b). The ongoing discharges of both ON- and OFF-cells were significantly altered after ipsilateral PB block, 


\section{CFA ( 5-6 d, lesion contralateral to CFA, block ipsilateral to CFA)}

a
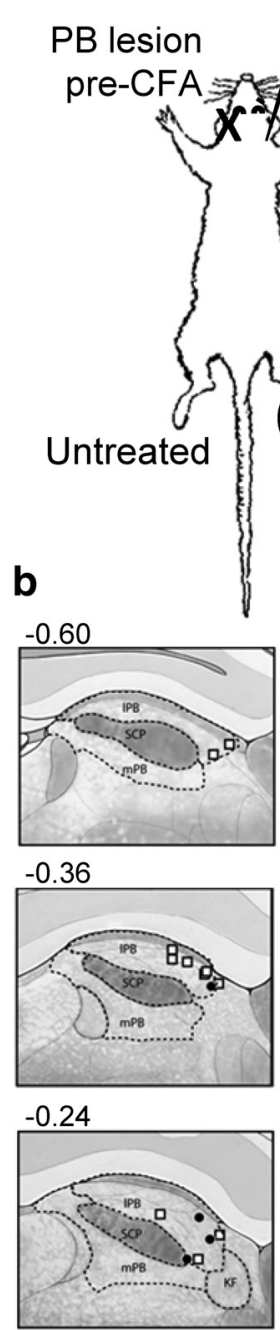

Acute PB block

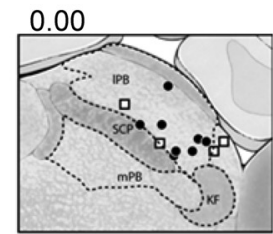

0.24

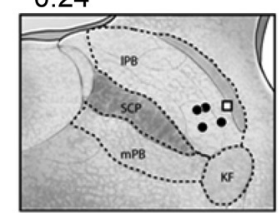

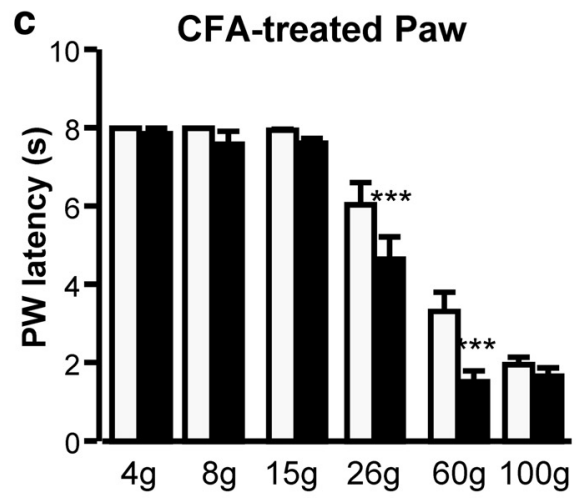

d

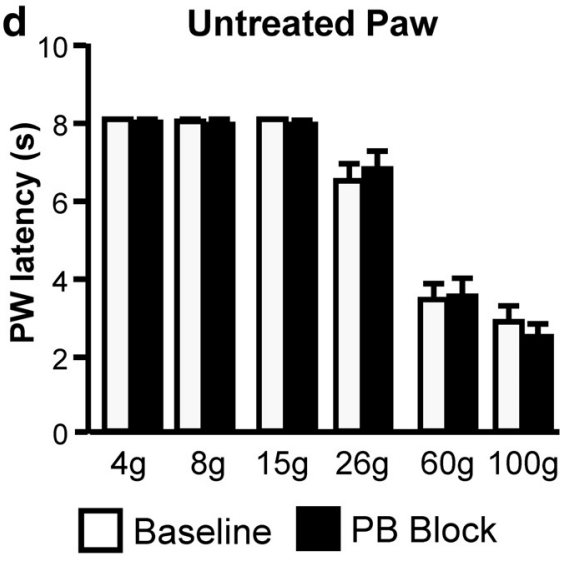

Figure 11. Excitotoxic lesion of $\mathrm{PB}$ contralateral to inflammation site, testing effect of acute block of remaining $\mathrm{PB}$ (ipsilateral to inflammation site). $\boldsymbol{a}$, Schematic of experimental setup with excitotoxic lesion of right PB followed by CFA injection in the left hindpaw. Stimulation was delivered to the inflamed paw (contralateral to lesion) and to the untreated paw (ipsilateral to lesion). $\boldsymbol{b}$, Locations of ibotenic acid microinjection in the right PB before CFA injection in the left hindpaw. Injection sites were distributed between +0.24 and $-0.60 \mathrm{~mm}$ relative to the interaural line. White squares represent ibotenic acid injection sites. Locations of muscimol injection in left PB during recording are also plotted (black circles). KF, Kölliker-Fuse; IPB, lateral parabrachial complex; $\mathrm{mPB}$, medial parabrachial area; scp, superior cerebellar peduncle. c, PB lesion prevented development of allodynia in the (FA-treated paw, and acute block of PB ipsilateral to the inflamed paw potentiated responding in the noxious range. There was a significant effect of force $\left(F_{(5,80)}=147.8, p<0.0001\right)$, block $\left(F_{(1,16)}=13.86, p=0.0018\right)$, and a force $\times$ block interaction $\left(F_{(5,80)}=4.86\right.$, $p=0.0006)$. $\boldsymbol{d}$, Untreated paw (contralateral to acute block) showed no change in withdrawal latency. There was a significant effect of force $\left(F_{(5,80)}=134, p<0.0001\right)$, but no effect of block $\left(F_{(1,16)}=0.14, p=0.71\right)$ or force $\times$ block interaction $\left(F_{(5,80)}=0.50, p=0.78\right) . \boldsymbol{e}, \boldsymbol{f}$, Examples of ibotenic acid-induced lesion $(\boldsymbol{e})$ compared with the control side $(\boldsymbol{f})$ in a single animal. Two-way ANOVA with repeated measures on force and block, followed by Sidak's test for multiple comparisons when the effect of block was significant. Values are the mean + SEM. ${ }^{* * *} p<0.001$ compared with preblock, $n=17$.

however (Fig. 12c), with a decrease in ON-cell firing and an increase in OFF-cell firing.

The fifth set of experiments thus demonstrates that $\mathrm{PB}$ contralateral to a prolonged inflammatory stimulus is required to recruit the ipsilateral $\mathrm{PB}$ in persistent inflammation, for sensitization of RVM pain-modulating neurons, and behavioral hyperalgesia. Moreover, just as in naive animals, $\mathrm{PB}$ block resulted in enhanced responding in the ipsilateral paw, suggesting that $\mathrm{PB}$ exerts a net antinociceptive influence on the ipsilateral limb. This latter influence is apparently independent of the RVM. Finally, these data show that RVM responses to noxious stimuli do not require ipsilateral or contralateral $\mathrm{PB}$ under conditions of chronic lesion of contralateral PB. This information must there- fore be relayed through a different pathway, such as direct spinoreticular projections or a through another structure such as the periaqueductal gray.

\section{Discussion}

There is strong evidence that spinoparabrachial neurons in the superficial dorsal horn contribute to persistent pain states. The role of PB itself, and specifically how it engages descending control systems, has received less attention. The present experiments demonstrate that contralateral $\mathrm{PB}$ is a principal relay of nociceptive information to RVM pain-modulating neurons under basal conditions and in acute inflammation, and is required for the initiation of hyperalgesia. By contrast, 


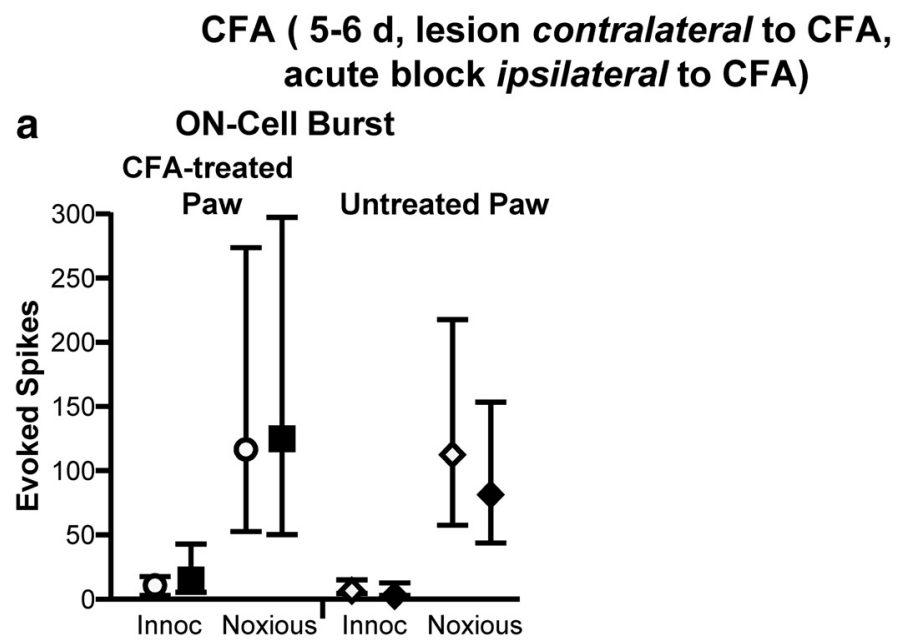

b OFF-Cell Pause
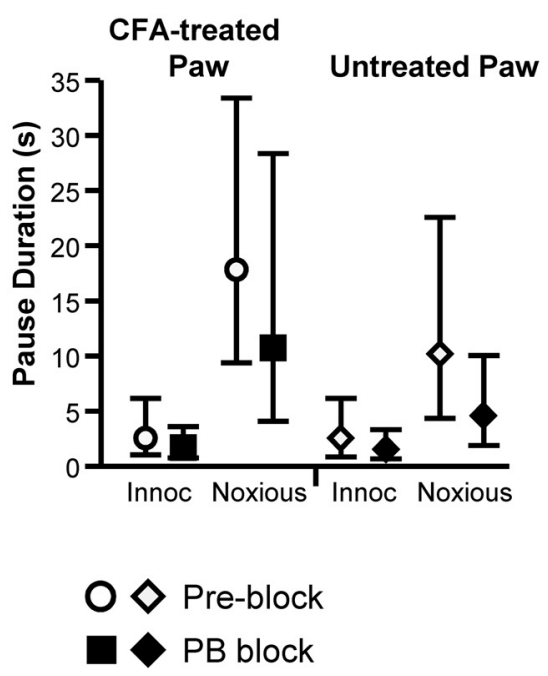

Figure 12. Inactivation of lateral PB ipsilateral to an inflamed paw did not attenuate the $\mathrm{ON}$-cell burst or OFF-cell pause evoked by mechanical stimulation of the inflamed or untreated paw in animals with lesions of $\mathrm{PB}$ contralateral to the inflammation site. $\boldsymbol{a}, 0 \mathrm{~N}$-cell burst. With stimulation of the inflamed paw (contralateral to the lesion and ipsilateral to the acute block), there was a significant effect of force $\left(F_{(1,9)}=100.6, p<0.0001\right)$, but no effect of block $\left(F_{(1,9)}=1.50, p=\right.$ 0.25). Similarly, with stimulation of the untreated paw (ipsilateral to the lesion and contralateral to the acute block), there was a significant effect of force $\left(F_{(1,9)}=172.8, p<0.0001\right)$, but no effect of block $\left(F_{(1,9)}=0.54, p=0.48, n=10\right)$. $\boldsymbol{b}$, OFF-cell pause. With stimulation of the inflamed paw (contralateral to the lesion and ipsilateral to the acute block), there was a significant effect of force $\left(F_{(1,9)}=43.88, p<0.0001\right)$, with no effect of block $\left(F_{(1,9)}=0.93, p=0.36\right)$. Similarly, with stimulation of the untreated paw (ipsilateral to the lesion and contralateral to the acute block), there was a significant effect of force $\left(F_{(1,9)}=29.98, p=0.0004\right)$, with no effect of block $\left(F_{(1,9)}=1.76, p=0.22, n=10\right)$. c, Ongoing firing of ON-cells was suppressed, while that of OFF-cells was increased (ON-cells: $t_{(9)}=5.26, p=0.0005, n=10$; 0FF-cells: $\left.t_{(9)}=4.11, p=0.0026, n=10\right)$. Evoked activity was analyzed using a two-way ANOVA with repeated measures on both stimulus force and block as factors, with Sidak's multiple-comparisons test used to compare responses during block with preblock baseline at each force when the effect of block was significant. Spontaneous activity before block was compared with that during block using $t$ tests for correlated means. Cell data are presented as the geometric mean with 95\% confidence intervals. ${ }^{* *} p<0.01,{ }^{* * *} p<0.001$ compared with preblock. Sp/s, Spikes per second; Innoc, Innocuous.

ipsilateral PB is recruited or unmasked in persistent inflammation, relays relevant information to RVM, and is required to maintain hyperalgesia.

PB contralateral to the site of acute noxious stimulation was shown previously to be an important relay of acute nociceptive information to RVM ON- and OFF-cells, and this activity contributes to basal nociceptive responsiveness (Roeder et al., 2016; Chen et al., 2017). The current experiments confirm those findings and demonstrate that $\mathrm{PB}$ contralateral to the site of injury remains an important relay to RVM ONand OFF-cells in acute inflammation, and that blocking PB contralateral to the acute inflammatory stimulus has an antihyperalgesic effect. However, the role of the contralateral $\mathrm{PB}$ as a driver of ON- and OFF-cell activity and hyperalgesia diminishes as inflammation continues. Instead, PB ipsilateral to the site of injury becomes the primary relay to RVM and contributes to localized behavioral hyperalgesia. Further, this input from PB ipsilateral to the site of injury is triggered through the contralateral PB. Together, these data reveal a dynamic process by which ipsilateral and contralateral PB differentially modulate RVM responsiveness and behavioral hyperalgesia as localized tissue inflammation develops and persists.

$\mathrm{PB}$ in nociceptive responsiveness in animals subjected to inflammation Animals exhibited robust mechanical allodynia in the CFA-treated hindpaw. In the first hour following the injection of CFA, blocking PB contralateral to the inflamed hindpaw significantly attenuated the ON-cell burst and OFF-cell pause evoked by stimulation of the inflamed paw, altered the balance between $\mathrm{ON}$ - and OFF-cell activity, and substantially reversed mechanical hypersensitivity. However, as inflammation continued (1-6 d after injection), contralateral block failed to consistently alter ON- or OFF-cell firing and did not reverse hyperalgesia.

While the capacity of PB contralateral to an inflamed paw to relay nociceptive information to RVM diminished with time, that of the ipsilateral PB increased. Thus, blocking PB ipsilateral to an inflamed hindpaw at 5-6 d post-CFA administration interfered with evoked responses in RVM, and resulted in a reduction in overall firing of ON-cells and an increase in that of OFF-cells. Behavioral hypersensitivity was also substantially attenuated. These data indicate that an ipsilateral parabrachial relay that conveys information to RVM painmodulating neurons and contributes to behavioral hypersensitivity is activated or unmasked as inflammation is established. This block also attenuated responses to noxious stimulation of the uninflamed paw, which was contralateral to the PB block. This latter effect was comparable to that of blocking contralateral $\mathrm{PB}$ in naive animals, indicating that the ability of $\mathrm{PB}$ to relay noxious information from the normal contralateral paw is preserved as the sensitization to ipsilateral stimuli develops. It would be interesting to know whether ipsilateral and contralateral PB play similar roles in the affective dimension of persistent pain. 


\section{Dynamic interaction of PB with RVM in persistent inflammation and contribution to behavioral hyperalgesia}

The current experiments provide direct evidence for the longassumed involvement of $\mathrm{PB}$ in the maintenance of persistent pain. This assumption was based on the analysis of parabrachial inputs to the central nucleus of the amygdala in persistent pain (Neugebauer, 2015) and on reports that the ablation of NK1 receptor-positive dorsal horn neurons, many of which project to $\mathrm{PB}$, diminishes behavioral hypersensitivity associated with localized inflammation of several days duration (Nichols et al., 1999; Suzuki et al., 2002). However, the intrathecal administration of neurotoxin approach does not differentiate ipsilateral from contralateral targets of the spinoparabrachial pathway and cannot confirm that PB itself is involved, since not all NK1 receptorpositive neurons in the dorsal horn project to the parabrachial complex (Littlewood et al., 1995; Todd, 2010). The current results imply that the reversal of behavioral antihyperalgesia by lesion of NK1 receptor-expressing dorsal horn neurons is due to loss of ascending spinoparabrachial projections. Moreover, the parallel changes in RVM neuronal responses and behavioral hypersensitivity suggest that RVM pain-modulating neurons mediate the descending influence of the contralateral PB under basal conditions and in acute inflammation, and of the ipsilateral PB in persistent inflammation. Since the NK1expressing neurons were lesioned before the induction of inflammation in the spinal ablation experiments, this approach likely prevented the engagement of contralateral PB and subsequent plasticity in the relevant circuit.

The behavioral responses to the stimulation of an uninflamed paw ipsilateral to a PB block (either in naive animals or with an inflamed paw contralateral to the PB block) were enhanced in naive controls and at 1 or 5-6 d post-CFA administration, occurring at a shorter latency. This hyper-responsiveness during block of ipsilateral PB indicates a net antinociceptive influence of the ipsilateral PB. This influence is likely not mediated by the RVM, since $\mathrm{ON}$ - and OFF-cell responses to noxious stimuli were not enhanced with this block, and the ongoing activity of ON-cells, which exert a pronociceptive effect, was not increased by the block at either time point. It is therefore possible that some cell populations in ipsilateral PB limits the development of chronic pain or supports the restoration of normal function and behaviors after injury, either through other brain circuits or via a direct projection from PB to the dorsal horn (Yoshida et al., 1997).

\section{Site of plasticity}

Plasticity at multiple levels likely contributes to the observation of the differential engagement of contralateral and ipsilateral PB in ongoing inflammation. A first possibility is that dorsal horn neurons projecting to contralateral and ipsilateral $\mathrm{PB}$ are differentially sensitized during inflammation. However, the majority of ipsilaterally projecting spinoparabrachial neurons also send branches to the contralateral PB (Spike et al., 2003). This would argue against a distinct ipsilateral spinoparabrachial projection important for persistent pain. A second possibility is plasticity within PB itself, which could change how circuits in this region process nociceptive information. A significant proportion of lateral PB neurons respond to noxious stimulation delivered over large, even whole-body, receptive fields under basal conditions (Bester et al., 1995), indicating that individual PB neurons frequently receive input from the ipsilateral as well as contralateral body. Studies using c-fos confirm bilateral activation of $\mathrm{PB}$ with noxious stimulation, although with contralateral predominance (Hermanson and Blomqvist, 1996; Bester et al., 1997). Interest- ingly, the contralateral predominance in c-fos expression is reduced with prolonged inflammation, with apparent parity between ipsilateral and contralateral expression at 24 or $96 \mathrm{~h}$ after CFA injection in the hindpaw (Bellavance and Beitz, 1996). Moreover, the sensitization of $\mathrm{PB}$ neurons in persistent pain has been reported. $\mathrm{PB}$ neurons show increased spontaneous activity in systemic arthritis produced by the injection of CFA in the tail (Matsumoto et al., 1996), and in animals subjected to nerve injury, $\mathrm{PB}$ neurons exhibit abnormal afterdischarges to stimulation delivered to sites distributed across the body (Uddin et al., 2018). Since PB sends both GABAergic and glutamatergic inputs to RVM (Chen et al., 2017), it is reasonable to suggest that the output and net functional influence of PB on RVM painmodulating neurons shift during inflammation. It will be critical to define the synaptic physiology linking PB to RVM painmodulating neurons, to determine whether this is lateralized, and to understand how it changes in persistent pain states. Indirect connections through which PB might influence RVM activity should be explored as well.

Finally, the observation that PB ipsilateral to an inflamed paw still relays information to RVM from the untreated control paw whereas blocking $\mathrm{PB}$ contralateral to an inflamed paw had no effect on RVM responses or behavioral sensitivity points to the RVM itself as a site of relevant plasticity. This possibility is strengthened by the fact that RVM neurons respond to noxious stimulation in animals with combined chronic lesion of contralateral $\mathrm{PB}$ and acute inactivation of ipsilateral $\mathrm{PB}$, which implies that RVM neurons are responsive to a normally silent input in persistent inflammation. Molecular and cellular studies document plasticity in RVM circuits in persistent pain states, with changes in NMDA, AMPA, trkB, opioid, and neurokinin 1 receptor expression and function (Heinricher, 2016). It could be imagined that RVM is sensitized by inputs relayed through the contralateral $\mathrm{PB}$ such that $\mathrm{ON}$ - and OFF-cells develop responses to normally less potent or less numerous inputs relayed through the ipsilateral PB. However, increased responsiveness of RVM neurons cannot be the entire explanation, since contralateral $\mathrm{PB}$ loses its ability to drive ON- and OFF-cells.

\section{Conclusion}

The present findings provide a circuit-level explanation for the observation that ablation of NK1-expressing dorsal horn neurons interferes with behavioral hyperalgesia in persistent inflammation (Nichols et al., 1999; Suzuki et al., 2002; Khasabov et al., 2005; Rivat et al., 2009). Our data demonstrate the different roles of contralateral and ipsilateral $\mathrm{PB}$ in persistent inflammatory pain, most likely via the engagement of pain-modulating neurons of the RVM. These data point to plasticity in PB itself or in the circuits linking PB to RVM as central to the development and maintenance of persistent inflammatory pain.

\section{References}

Bellavance LL, Beitz AJ (1996) Altered $c$-fos expression in the parabrachial nucleus in a rodent model of CFA-induced peripheral inflammation. J Comp Neurol 366:431-447.

Bernard JF, Peschanski M, Besson JM (1989) A possible spino (trigemino)ponto-amygdaloid pathway for pain. Neurosci Lett 100:83-88.

Bernard JF, Dallel R, Raboisson P, Villanueva L, Le Bars D (1995) Organization of the efferent projections from the spinal cervical enlargement to the parabrachial area and periaqueductal gray: a PHA-L study in the rat. J Comp Neurol 353:480-505.

Bester H, Menendez L, Besson JM, Bernard JF (1995) Spino (trigemino) parabrachiohypothalamic pathway: electrophysiological evidence for an involvement in pain processes. J Neurophysiol 73:568-585.

Bester H, Matsumoto N, Besson JM, Bernard JF (1997) Further evidence for 
the involvement of the spinoparabrachial pathway in nociceptive processes: a c-fos study in the rat. J Comp Neurol 383:439-458.

Bester H, Beggs S, Woolf CJ (2000a) Changes in tactile stimuli-induced behavior and c-fos expression in the superficial dorsal horn and in parabrachial nuclei after sciatic nerve crush. J Comp Neurol 428:45-61.

Bester H, Chapman V, Besson JM, Bernard JF (2000b) Physiological properties of the lamina I spinoparabrachial neurons in the rat. J Neurophysiol 83:2239-2259.

Bourgeais L, Monconduit L, Villanueva L, Bernard JF (2001) Parabrachial internal lateral neurons convey nociceptive messages from the deep laminas of the dorsal horn to the intralaminar thalamus. J Neurosci 21:2159-2165.

Carrasquillo Y, Gereau RW 4th (2008) Hemispheric lateralization of a molecular signal for pain modulation in the amygdala. Mol Pain 4:24-28.

Chen Q, Roeder Z, Li MH, Zhang Y, Ingram SL, Heinricher MM (2017) Optogenetic evidence for a direct circuit linking nociceptive transmission through the parabrachial complex with pain-modulating neurons of the rostral ventromedial medulla (RVM). eNeuro 4:ENEURO.0202-17.2017.

Cleary DR, Heinricher MM (2013) Adaptations in responsiveness of brainstem pain-modulating neurons in acute compared with chronic inflammation. Pain 154:845-855.

Feil K, Herbert H (1995) Topographic organization of spinal and trigeminal somatosensory pathways to the rat parabrachial and Kölliker-Fuse nuclei. J Comp Neurol 353:506-528.

Guan Y, Terayama R, Dubner R, Ren K (2002) Plasticity in excitatory amino acid receptor-mediated descending pain modulation after inflammation. J Pharmacol Exp Ther 300:513-520.

Guan Y, Guo W, Zou SP, Dubner R, Ren K (2003) Inflammation-induced upregulation of AMPA receptor subunit expression in brain stem pain modulatory circuitry. Pain 104:401-413.

Han S, Soleiman MT, Soden ME, Zweifel LS, Palmiter RD (2015) Elucidating an affective pain circuit that creates a threat memory. Cell 162:363-374.

Heinricher MM (2016) Pain modulation and the transition from acute to chronic pain. Adv Exp Med Biol 904:105-115.

Heinricher MM, Fields HL (2013) Central nervous system mechanisms of pain modulation. In: Wall and Melzack's textbook of pain, Ed 6 (McMahon S, Koltzenburg M, Tracey I, Turk DC, eds), pp 129-142. London: Elsevier.

Heinricher MM, Tavares I, Leith JL, Lumb BM (2009) Descending control of nociception: specificity, recruitment and plasticity. Brain Res Rev 60:214-225.

Hermanson O, Blomqvist A (1996) Subnuclear localization of FOS-like immunoreactivity in the rat parabrachial nucleus after nociceptive stimulation. J Comp Neurol 368:45-56.

Khasabov SG, Ghilardi JR, Mantyh PW, Simone DA (2005) Spinal neurons that express NK-1 receptors modulate descending controls that project through the dorsolateral funiculus. J Neurophysiol 93:998-1006.

Littlewood NK, Todd AJ, Spike RC, Watt C, Shehab SA (1995) The types of neuron in spinal dorsal horn which possess neurokinin-1 receptors. Neuroscience 66:597-608.

Maduka UP, Hamity MV, Walder RY, White SR, Li Y, Hammond DL (2016)
Changes in the disposition of substance $\mathrm{P}$ in the rostral ventromedial medulla after inflammatory injury in the rat. Neuroscience 317:1-11.

Matsumoto N, Bester H, Menendez L, Besson JM, Bernard JF (1996) Changes in the responsiveness of parabrachial neurons in the arthritic rat: an electrophysiological study. J Neurophysiol 76:4113-4126.

Neugebauer V (2015) Amygdala pain mechanisms. Handb Exp Pharmacol 227:261-284.

Nichols ML, Allen BJ, Rogers SD, Ghilardi JR, Honore P, Luger NM, Finke MP, Li J, Lappi DA, Simone DA, Mantyh PW (1999) Transmission of chronic nociception by spinal neurons expressing the substance $P$ receptor. Science 286:1558-1561.

Paxinos G, Watson C (2009) The rat brain in stereotaxic coordinates, compact Ed 6. Amsterdam: Academic.

Polgár E, Wright LL, Todd AJ (2010) A quantitative study of brainstem projections from lamina I neurons in the cervical and lumbar enlargement of the rat. Brain Res 1308:58-67.

Porreca F, Ossipov MH, Gebhart GF (2002) Chronic pain and medullary descending facilitation. Trends Neurosci 25:319-325.

Ren K, Dubner R (1996) Enhanced descending modulation of nociception in rats with persistent hindpaw inflammation. J Neurophysiol 76:3025-3037.

Ren K, Dubner R (2002) Descending modulation in persistent pain: an update. Pain 100:1-6.

Rivat C, Vera-Portocarrero LP, Ibrahim MM, Mata HP, Stagg NJ, De Felice M, Porreca F, Malan TP (2009) Spinal NK-1 receptor-expressing neurons and descending pathways support fentanyl-induced pain hypersensitivity in a rat model of postoperative pain. Eur J Neurosci 29:727-737.

Rodriguez E, Sakurai K, Xu J, Chen Y, Toda K, Zhao S, Han BX, Ryu D, Yin H, Liedtke W, Wang F (2017) A craniofacial-specific monosynaptic circuit enables heightened affective pain. Nat Neurosci 20:1734-1743.

Roeder Z, Chen Q, Davis S, Carlson JD, Tupone D, Heinricher MM (2016) The parabrachial complex links pain transmission to descending pain modulation. Pain 157:2697-2708.

Spike RC, Puskár Z, Andrew D, Todd AJ (2003) A quantitative and morphological study of projection neurons in lamina I of the rat lumbar spinal cord. Eur J Neurosci 18:2433-2448.

Suzuki R, Morcuende S, Webber M, Hunt SP, Dickenson AH (2002) Superficial NK1-expressing neurons control spinal excitability through activation of descending pathways. Nat Neurosci 5:1319-1326.

Thompson JM, Neugebauer V (2017) Amygdala plasticity and pain. Pain Res Manag 2017:8296501.

Todd AJ (2010) Neuronal circuitry for pain processing in the dorsal horn. Nat Rev Neurosci 11:823-836.

Todd AJ, McGill MM, Shehab SA (2000) Neurokinin 1 receptor expression by neurons in laminae I, III and IV of the rat spinal dorsal horn that project to the brainstem. Eur J Neurosci 12:689-700.

Uddin O, Studlack P, Akintola T, Raver C, Castro A, Masri R, Keller A (2018) Amplified parabrachial nucleus activity in a rat model of trigeminal neuropathic pain. Neurobiol Pain 3:22-30.

Yoshida A, Chen K, Moritani M, Yabuta NH, Nagase Y, Takemura M, Shigenaga Y (1997) Organization of the descending projections from the parabrachial nucleus to the trigeminal sensory nuclear complex and spinal dorsal horn in the rat. J Comp Neurol 383:94-111. 